\title{
Enhancement of Agro-Industrial Waste Composting Process via the Microbial Inoculation: A Brief Review
}

\author{
Mohd Huzairi Mohd Zainudin ${ }^{1, *}$, Aisyah Zulkarnain ${ }^{1}$, Ain Sahira Azmi ${ }^{1}$, Shalini Muniandy ${ }^{1}$, Kenji Sakai ${ }^{2}$, \\ Yoshihito Shirai ${ }^{3}$ and Mohd Ali Hassan ${ }^{4,5}$
}

check for updates

Citation: Zainudin, M.H.M.; Zulkarnain, A.; Azmi, A.S.; Muniandy, S.; Sakai, K.; Shirai, Y.; Hassan, M.A. Enhancement of Agro-Industrial Waste Composting Process via the Microbial Inoculation: A Brief Review. Agronomy 2022, 12, 198. https://doi.org/10.3390/ agronomy12010198

Academic Editors:

Ravindran Balasubramani, Mukesh Kumar Awasthi, Sunita Varjani and

Natchimuthu Karmegam

Received: 16 December 2021

Accepted: 10 January 2022

Published: 14 January 2022

Publisher's Note: MDPI stays neutral with regard to jurisdictional claims in published maps and institutional affiliations.

Copyright: (C) 2022 by the authors. Licensee MDPI, Basel, Switzerland. This article is an open access article distributed under the terms and conditions of the Creative Commons Attribution (CC BY) license (https:// creativecommons.org/licenses/by/ $4.0 /)$.
1 Laboratory of Sustainable Animal Production and Biodiversity, Institute of Tropical Agriculture and Food Security, Universiti Putra Malaysia, Serdang 43400, Selangor, Malaysia; ecahzul90@gmail.com (A.Z.); ainsahiraazmi@gmail.com (A.S.A.); shalinimuniandy0108@gmail.com (S.M.)

2 Laboratory of Soil and Environmental Microbiology, Division of Systems Bioengineering, Department of Bioscience and Biotechnology, Faculty of Agriculture, Graduate School of Bioresources and Bioenvironmental Sciences, Kyushu University, 744 Motooka, Nishi-ku, Fukuoka 819-0395, Japan; kensak@agr.kyushu-u.ac.jp

3 Department of Biological Function and Engineering, Graduate School of Life Science and System Engineering, Kyushu Institute of Technology, 2-4 Hibikino, Wakamatsu-ku, Fukuoka 808-0196, Japan; shirai@life.kyutech.ac.jp

4 Department of Bioprocess Technology, Faculty of Biotechnology and Biomolecular Sciences, Universiti Putra Malaysia, Serdang 43400, Selangor, Malaysia; alihas@upm.edu.my

5 Laboratory of Processing and Product Development, Institute of Plantation Studies, Universiti Putra Malaysia, Serdang 43400, Selangor, Malaysia

* Correspondence: mohdhuzairi@upm.edu.my; Tel.: +603-97694287

\begin{abstract}
Composting is an important technology used to treat and convert organic waste into value-added products. Recently, several studies have been done to investigate the effects of microbial supplementation on the composting of agro-industrial waste. According to these studies, microbial inoculation is considered to be one of the suitable methods for enhancing the biotransformation of organic materials during the composting process. This review provides up-to-date research findings on microbial inoculation strategies and their role and functions in enhancing the composting process and the improvement of compost quality. Based on this review, the addition of microorganisms could enhance the composting process such as accelerating the organic matter degradation, mineralization and microbial enzymes activities, and the quality of the end-products such as high germination index. It is important to notice in this strategy that sludge's microbial consortium is feasible to enhance the composting process in pilot-scale and industrial-scale productions. Besides, it also reduces the cost of compost production. The findings of this review show the various positive impact of microbial inoculation on agro-industrial waste composting which in turn might be useful as a reference for selecting a suitable inoculum based on the type of waste materials.
\end{abstract}

Keywords: agro-industrial waste; composting enhancement; single-stage inoculation; multiple-stage inoculation; bacteria and fungi inoculation

\section{Introduction}

The increase in human population indirectly contributes to the increasing demand for various agro-industrial-based products. Currently, the agriculture sector contributed 4\% (USD 87.7 billion) of the world's Gross Domestic Product (GDP) for the year 2019 [1]. The data shown in Table 1 represents the world's total production and yield of various agro-industrial crops in 2017 and 2018 [2]. It can be observed that the production of agroindustrial crops and the yield of the products harvested are increasing year by year to meet the market demand. Hence, the high production of agro-industrial-based products will subsequently increase the generation of waste and residues. Agro-industry is responsible for the production of various residues related to agricultural and industrial activities [3]. Looking on the bright side of the waste production trend, these potential substrates can 
be utilized for recycling which will help to promote the sustainability of the agriculture industry. It is notable that, almost 2.0 billion tons/year of agricultural waste are being produced worldwide with an estimated average increase rate of 5 to $10 \%$ per annum [4]. Nevertheless, if these residues are discharged into the environment without proper disposal protocol, it may cause great pollution and harmful effects on animal and human health [5]. Therefore, effective management of treating these wastes is important to promote the efforts concerning the development of a sustainable society.

Table 1. World's total production and yield based on area harvested for various agro-industrial crops in year 2017 to 2020 [2].

\begin{tabular}{|c|c|c|c|c|c|}
\hline & \multirow[b]{2}{*}{ Crop } & \multicolumn{4}{|c|}{ Year } \\
\hline & & 2017 & 2018 & 2019 & 2020 \\
\hline \multirow{11}{*}{ Area harvested (million ha) } & Barley & 48 & 48 & 51.0 & 51 \\
\hline & Cocoa, beans & 12 & 12 & 12.0 & 12 \\
\hline & Coffee, green & 10 & 11 & 11 & 11 \\
\hline & Maize & 198 & 195 & 196 & 201 \\
\hline & Millet & 31 & 32 & 30 & 32 \\
\hline & Oil palm fruit & 27 & 27 & 28 & 28 \\
\hline & Oranges & 3.8 & 3.9 & 3.9 & 3.8 \\
\hline & Rice, paddy & 164 & 165 & 161 & 164 \\
\hline & Sugar beet & 4.9 & 4.8 & 4.6 & 4.4 \\
\hline & Sugar cane & 26 & 26 & 26 & 26 \\
\hline & Wheat & 218 & 214 & 215 & 219 \\
\hline \multirow{11}{*}{ Production (million tons) } & Barley & 148 & 139 & 158 & 157 \\
\hline & Cocoa, beans & 5.2 & 5.5 & 5.6 & 5.6 \\
\hline & Coffee, green & 9.3 & 10 & 10 & 10 \\
\hline & Maize & 1138 & 1124 & 1141 & 1162 \\
\hline & Millet & 29 & 32 & 28 & 30 \\
\hline & Oil palm fruit & 406 & 409 & 415 & 418 \\
\hline & Oranges & 73 & 73 & 75 & 75 \\
\hline & Rice, paddy & 747 & 759 & 749 & 757 \\
\hline & Sugar beet & 313 & 273 & 280 & 252 \\
\hline & Sugar cane & 183 & 193 & 195 & 187 \\
\hline & Wheat & 772 & 732 & 765 & 761 \\
\hline \multirow{11}{*}{ Yield (hg/ha) } & Barley & 31,014 & 29,243 & 31,060 & 30,432 \\
\hline & Cocoa, beans & 4478 & 4626 & 4640 & 4674 \\
\hline & Coffee, green & 9022 & 9756 & 9069 & 9679 \\
\hline & Maize & 57,452 & 57,542 & 58,127 & 57,547 \\
\hline & Millet & 9212 & 9679 & 9202 & 9485 \\
\hline & Oil palm fruit & 150,255 & 147,556 & 146,434 & 145,614 \\
\hline & Oranges & 188,312 & 192,285 & 193,660 & 194,251 \\
\hline & Rice, paddy & 45,539 & 45,795 & 46,312 & 46,089 \\
\hline & Sugar beet & 630,328 & 571,355 & 604,012 & 569,869 \\
\hline & Sugar cane & 697,722 & 727,979 & 726,377 & 706,434 \\
\hline & Wheat & 35,377 & 34,222 & 35,432 & 34,744 \\
\hline
\end{tabular}

Among the various waste management systems, composting is considered as the sustainable treatment method for recycling agro-industrial waste into valuable by-products [6]. To date, the production of compost using agro-industrial waste has been extensively used by many researchers due to the availability of cheap and abundant resources [7-9]. Agroindustrial waste mainly consists of complex lignocellulosic materials such as cellulose, hemicellulose and lignin. Despite being a suitable method for treating agricultural residues, one of the most common challenges for the composting of this type of waste is the difficulty of decomposing recalcitrant compounds such as cellulose, hemicellulose and lignin. This obstacle affects the productivity of the composting process and the quality of the end product. Moreover, it increases the cost of operations, energy and time in compost production. 
Various composting strategies had been proposed by researchers aiming to improve the composting process and to produce good quality end-products. This includes monitoring and controlling the key parameters such as $\mathrm{C} / \mathrm{N}$ ratio, moisture and aeration to provide an optimum condition for composting process. Previous technologies have used pre-treatment methods such as hydrothermal and chemical treatments of the raw materials mainly to break the lignin structure and remove other recalcitrant components before the composting process [10]. However, these pre-treatment methods are not practical, especially for the pilot and industrial scale, due to the high energy and chemical inputs needed. Therefore, finding a safe, sustainable and cost-effective treatment method is necessarily required. Recently, supplementation of microbial inoculant is seen as an attractive solution and there has been growing interest as reported in several studies involving microbial inoculant supplements in the compost pile as a means to enhance productivity and end-product quality of the composting process [11-15].

Various interesting and enlightening studies on the topic of composting of agroindustrial waste, covering the impact of biochar, chemical fertilizer, and mineral amendment have been published and highlighted earlier [16,17]. However, based on the current literature search, limited review articles are describing microbial inoculation, especially for agro-industrial waste composting. The previous study claims that microbial inoculation is less practical than optimizing the physicochemical parameters of the composting process especially for municipal solid waste [7]. However, recent studies have suggested that inoculation of composting with lignocellulosic waste increase the rate of organic matter degradation, temperature, humification, and maturity $[7,18,19]$. In view of the effectiveness of microbial inoculation for lignocellulose composting, this review aimed to evaluate the state of the latest developments and the understanding of compost supplementation with microorganisms and their roles in the biotransformation of organic materials during the composting process of agro-industrial waste. This review gave an overview of the effectiveness of microbial inoculation which will then serve as a reference for choosing the suitable microbes based on the type of waste.

\section{Composting for Agro-Industrial Waste Treatment and Utilization}

Composting is a self-heating aerobic biodegradative process of organic matter that is carried out under controlled conditions via microbial activities to produce valuable, stable, humus-rich products useful for the cultivation of crops and the soil. In addition, composting is an alternative to the landfill and incineration approaches for waste disposal. As a safe and economical process, several agriculture-based industries have adopted composting technology as a treatment method in their waste management system. The use of this system to convert organic waste into valuable decomposed by-products promotes the reduction of waste treatment costs. In general, industrial activities involving the processing of certain crops or livestock generate an abundance of agro-industrial residues. These residues present either in solid or liquid forms and are mainly composed of complex proteins, carbohydrates, and polyphenolic constituents [20,21]. Agricultural residues can be classified into (a) field residues such as leaves, stalks, seed pods, stems that remain in the field after crop harvesting and (b) process residues such as molasses, husks, bagasse, seeds, leaves, stem, straw, stalk, shell, pulp, stubble, peel and roots which are present after the crops are processed into valuable products [22]. For example, in the sugarcane industry, residues are generated from two different stages: the first stage is from agricultural activities which produce field residues and the second stage is from the industrial stage which produces process residues. The two main residues from agricultural activities are cane tops and dry leaves which are generated from cane cultivation while filter mud, bagasse and ash generated from the juice clarification process, cane squeezing and burning of bagasse, respectively, are the main residues of the industrial stage in the sugarcane industry [23]. In Malaysia, the palm oil industry alone is estimated to generate 80 million tons of solid biomass composed of oil palm empty fruit bunch, frond, mesocarp fiber and trunk and 60 million tons of palm oil mill effluent (POME) per annum [24]. It is also estimated that 
from the sugarcane industry, an average of $30 \mathrm{~kg}$ of filter cake will be generated from a ton of ground sugarcane [25]. In 2014 alone, approximately 19.04 million tons of filter cake were generated from a total of 634.77 million tons of processed sugarcane in Brazil. Thus, choosing agro-industrial waste as the composting material can be considered a good choice due to its availability throughout the year. However, in some European and Asian countries, the generation of agro-industrial residues are mainly relying on the seasons of the year, which limits the availability of the waste produced. Table 2 summarizes several types of agro-industrial wastes which have been used as composting feedstock in recent years.

Table 2. Composting of agro-industrial waste in recent years by several works of literature.

\begin{tabular}{ll}
\hline Type of Agro-Industry & Feedstock \\
\hline Oil palm & $\begin{array}{l}\text { Oil palm empty fruit bunch } \\
\text { (OPEFB) }\end{array}$
\end{tabular}

\begin{tabular}{|c|c|c|}
\hline Paddy & Paddy husk & $\begin{array}{l}\text { Co-composting of paddy husk and chicken slurry with } \\
\text { clinoptilolite zeolite and urea. }\end{array}$ \\
\hline & Paddy straw & $\begin{array}{l}\text { Single-strain or mixed cultures of Bacillus licheniformis } 1-1 \mathrm{v} \\
\text { and Bacillus sonorensis } 7-1 \mathrm{v} \text { were inoculated in composting } \\
\text { of rice straw. }\end{array}$ \\
\hline
\end{tabular}

Sugarcane Bagasse

Filter cake and ash

\section{Composting Description}

OPEFB was kept individually at $15 \mathrm{~cm}$ apart inside a

sheltered building with walls, good air ventilation, at room temperature around $27-28^{\circ} \mathrm{C}$.

OPEFB compost was added with activated liquid organic fertilizer (ALOF) in basket composer. Sand and rice husk were added to the mixture 1:1:1, 1:3:1, 1:0:1.

OPEFB mixed with activated liquid organic fertilizer (ALOF) in tower composter.

Two effective Trichoderma strains were mixed with OPEFB in the plastic bags and tightly closed with rubber bands.

Co-composting of oil palm empty fruit bunch (OPEFB) and palm oil mill effluent (POME) anaerobic sludge with ratio 1:1.

Co-composting of paddy straw with cattle manure, farmyard manure and poultry manure. Inoculated with Aspergillus niger ITCC 6719, Aspergillus flavus ITCC 6720 and Trichoderma harzianum ITCC 6721.

Co-composting of poultry manure and paddy straw with five treatment combinations in plastic pots of $10 \mathrm{~kg}$ capacity and in composting pits of the size of $1 \mathrm{~m} \times 1 \mathrm{~m} \times$ $0.5 \mathrm{~m}$ for each treatment.

Two methods are applied: in-vessel composting for five mixtures and windrow composting for two mixtures. The mixtures are composed of cow dung, dry leaves, bagasse, filter mud and furnace ash. All compost piles consist of filter cake, boiler and fly ash (2:1) with laying of chicken manure.

Co-composting coffee husk and pulp with source-separated municipal solid waste in different proportions $(0,33,50$ and $100 \%)$.

Reference

Co-composting coffee husk with cow dung, poultry manure and Desmodium triflorum.

\section{[33]}


Table 2. Cont.

\begin{tabular}{|c|c|c|c|}
\hline Type of Agro-Industry & Feedstock & Composting Description & Reference \\
\hline Wheat & Wheat straw & $\begin{array}{l}\text { Different wheat straw sizes, nitrogen addition and } \\
\text { Trichoderma harzianum were applied and the composting } \\
\text { process was carried out with } 500 \mathrm{~g} \text { of wheat straw styrene } \\
\text { boxes in a dark room at } 30-35^{\circ} \mathrm{C} \text {. }\end{array}$ & {$[37]$} \\
\hline \multirow[t]{2}{*}{ Maize } & Maize straw & $\begin{array}{l}\text { Maize straw composting with a spent mushroom } \\
\text { substrate, earthworm casts and zeolite as an additive. }\end{array}$ & {$[38]$} \\
\hline & & $\begin{array}{l}\text { Maize straw was placed in piles (length, } 10 \mathrm{~m} \text {; width, } 3 \mathrm{~m} \text {; } \\
\text { height, } 1.5 \mathrm{~m} \text { ). }\end{array}$ & {$[39]$} \\
\hline \multirow[t]{2}{*}{ Mushroom } & Spent mushroom substrate & $\begin{array}{l}\text { Sewage sludge mixed with different dosages of spent } \\
\text { mushroom substrate. }\end{array}$ & {$[40]$} \\
\hline & & $\begin{array}{l}\text { The spent mushroom substrate was mixed with } 2 \% \\
\mathrm{CaSO}_{4}, 0.5 \% \text { mineral salt, small amounts of lime water } \\
\text { and conducted with a combined static, heap-turning } \\
\text { composting process. }\end{array}$ & {$[41]$} \\
\hline
\end{tabular}

Compost production from different types of agro-industrial waste improves the soil $\mathrm{pH}$, organic carbon and nitrogen, cation exchange and water holding capacity as well as reducing the potential for erosion and runoff and permanent wilting point in the soil [23]. Lou et al. [41] reported that the application of mature composts derived from spent mushroom substrate increased the nitrogen content in the soil from $157.35 \mathrm{mg} \mathrm{N} \mathrm{kg}^{-1}$ to $400 \mathrm{mg} \mathrm{N} \mathrm{kg}^{-1}$ after 42 days of incubation as compared to the control. On the other hand, compost application also increased exchangeable sodium, potassium, calcium, magnesium, iron and copper as well as improved onion shoot numbers, shoot girth and shoot length [42].

Prominently, the advantages of compost application are not only to enrich soil biological fertility by stimulating the growth of beneficial bacteria but also for controlling soil-borne pathogens, specifically as several of these pathogens co-exist in soil. The presence of soil-borne plant pathogens can greatly decrease crop yield. It is not an easy task to combat these pathogens as they habitually survive in the soil for many years. Thus, the application of compost has been extensively practiced by numerous researchers to suppress soil-borne pathogens. This showed positive impacts as reviewed by Patil et al. [43] and Mehta et al. [44]. In addition, during the composting process, potentially pathogenic bacteria present in the agro-industrial waste can be eliminated, thus ensuring the safety of the compost before application for agriculture purposes. Estrada-Bonilla et al. [25] reported the existence of bacteria from the order Xanthomonadales known as a plant pathogenic bacterium at the initial stage of the composting. However, their numbers reduced after the composting process took place due to high temperature $\left(>55^{\circ} \mathrm{C}\right)$ during the thermophilic phase, which hampered the pathogen's development.

At the moment, intensive agricultural practices are characterized by extreme usage of chemical fertilizers, pesticides and herbicides [22]. Even though chemical fertilizers can increase crop yield, the production and use of these chemicals contribute several destructive effects on the agroecosystem such as degradation of the soil, harm of crop genetic diversity, reduction in soil microbial diversity and depletion of ground-water resources and atmospheric pollution [45]. Zhao et al. [46] reported that the use of a mixture of organic pig manure compost-inorganic compound fertilizer with reduced chemical fertilizer had been found to significantly increase the yields of wheat and rice than in the unfertilized control. Likewise, the results showed that at all sampling times, this fertilizer regime improved the soil nutrients, microbial biomass, enzymatic activities and soil nitrogen transformation processes. This showed that the application of organic-inorganic compound fertilizer reduced chemical fertilizer usage and thus, maintained the long-term productivity and sustainability of the agroecosystems. 
The use of mixed fertilizer consisting of chemical fertilizers, compost, and clinoptilolite zeolite had been reported to increase the production of higher grain yield of maize as compared with the application of chemical fertilizers only [47]. Furthermore, the addition of mature compost of coffee husk and pulp with source-separated municipal solid waste increases the weight of the cabbage (572 $\pm 10 \mathrm{~g} \mathrm{~kg}^{-1}$ of compost) as compared to the control [35]. A similar study also showed that the application of the pro-mix with 10\% coffee pulp compost greatly improved aerial biomass, seedling height, and the number of nodes per plant when compared to pure pro-mix medium, demonstrating the great benefit of using compost as a supplement in promoting plant development [48].

\section{Inoculation Strategies for Enhancing the Composting Process}

Conventional composting of agro-industrial waste can be challenging and timeconsuming. There are so many factors affecting the composting process such as raw materials, times, environmental conditions, and so on. Previous studies showed the addition of inoculum gave no effect on the degradation of organic matter during composting of wheat straw, farm waste and grapes' pulp [49,50]. The inoculation does not always show a good performance due to the competition between inoculant and indigenous microbes, the timing of inoculation and the type of inoculation. Therefore, various strategies have been tried by researchers in order to improve the composting process with the addition of inoculums. One of the promising approaches is by adding microbial inoculum at different stages of the composting process. An overview of the composting process with the addition of inoculum is illustrated in Figure 1.

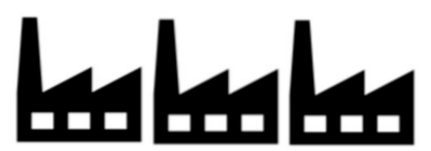

Agro-industrial activities

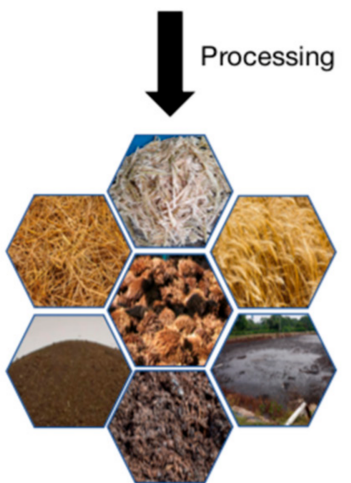

Residues / Feedstocks

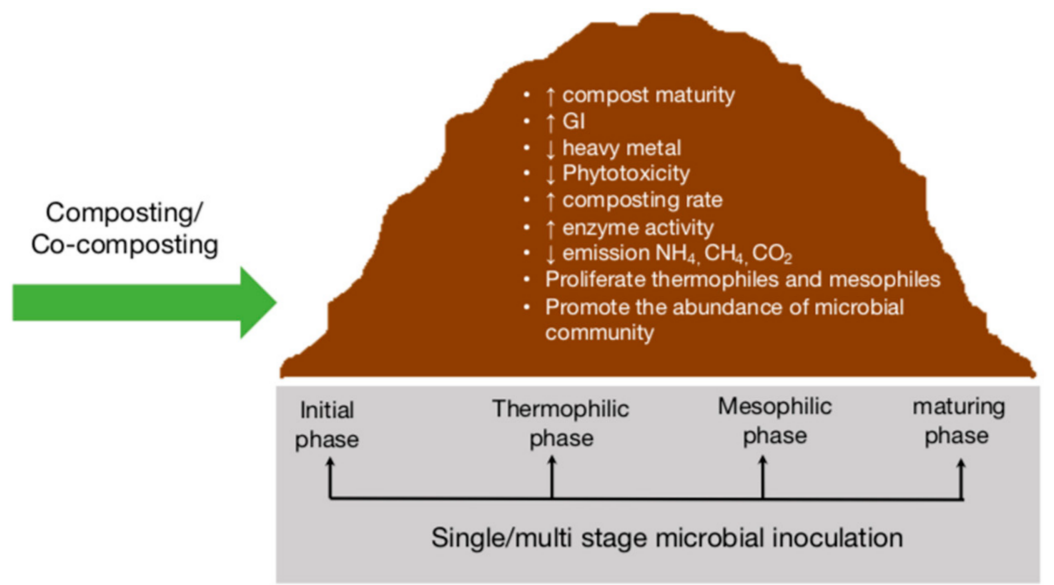

Figure 1. Overview of the composting process with the addition of inoculum.

The microbial inoculum can be added either in a single stage, two-stages or multistages of the composting process, and a significant impact on physicochemical parameters can be seen when the inoculum was added at different stages of the composting process [51,52]. For example, a study by Zeng et al. [53] indicated that the addition of Phanerochaete chrysosporium during the second phase promotes a significant change in compost maturity as compared to the inoculation during the first phase of agricultural waste (rice straw + bran + vegetable) composting process. The bacterial inoculation at different stages of rice straw [54], maize straw [55] and peel citrus [9] composting showed a significant enhancement of lignocellulose degradation, thus, reducing the $\mathrm{C} / \mathrm{N}$ ratio and composting period. A review by Fan et al. [7] reported that the microbial inoculation on 
composting of lignocellulosic waste showed almost $100 \%$ positive effect on temperature, enzyme activity, microbial population, $\mathrm{C} / \mathrm{N}$ ratio, humification, and more than $50 \%$ on organic matter degradation, germination index (GI) and N, P, K. However, their study indicated that the addition of microbe is less effective for the composting of municipal solid waste. This is because municipal solid waste contains readily degradable organic matter that can be degraded by existing or indigenous microbes. It should be noted that monitoring of microbial inoculants is required to ensure the survival of inoculant and their impact on indigenous microbe by comparing the microbial succession with the uninoculated composting process. This can be done through culture-based methods or culture-independent methods such as polymerase chain reaction-denaturing gradient gel electrophoresis (PCR-DGGE) and high-throughput $16 \mathrm{~S}$ rRNA gene sequencing $[30,56]$.

As mentioned above, the inoculation of efficient microbes demonstrates numerous positive impacts on the composting process as revealed by several researchers. The microbial inoculum can be composed of (i) a single culture, (ii) mixed culture and (iii) mature compost as shown in Figure 1. Several efficient microbes' cultures, a widely used compost inoculum, are made up of a combination of non-dominant and dominant microbes [57]. It has been suggested that the addition of a microbial consortium would be the best to overcome the problem of competing with indigenous microbes of the composting pile. Another strategy that could give a positive impact on the composting performance is the re-inoculation of isolated microbes from the composting itself. It has been suggested that the microbial inoculation with specific bacteria and/or enzyme-producing microbes (enzymes are excreted chemicals that break down molecular compounds into simpler forms) could enhance the composting process by ensuring the right microbes are added in the right temperature, oxygen and moisture regimes in the piles at the right times. This has been shown in a study conducted by Zhou et al. [54] in which the temperature and the cellulose and lignin degradation rate of the dairy manure-rice straw composting is enhanced through the inoculation of thermophilic Thermoactinomyces sp. at the initial stage followed by ligninolytic Coprinus cinarea and Coprinus comatus after thermophilic stage and finally, cellulolytic Trichoderma harzanium and Rhizopus oryzae during the maturing stage. More importantly, all of these inoculants were isolated from the dairy manure-rice straw compost. Inoculating fresh feedstocks with acclimated microbes from the composting process by either mixing in overs and/or recycling some compost could also be a suitable method for bringing compost piles up to acceptable temperatures quickly.

On the other hand, it should be emphasized that certain research implies that the use of commercially effective microbes $\left(\mathrm{EM}^{\circledR}\right)$ in the composting process has significant drawbacks. This is due to inconsistencies in the development of EM during the composting process. Climate conditions and raw material properties are among the factors that generate an environment that is less favorable for the inoculant to grow, live, and function effectively during the composting process [58-60]. According to van Vliet et al. [61], adding EM to slurry manure composting to reduce nitrogen loss resulted in no significant difference in $\mathrm{N}$ mineral: $\mathrm{N}$ organic ratio between treatment and control, indicating that EM did not influence compost quality. Moreover, a comparison of microbial profiles between the EM-manure composting and the EM solution showed that many of the bacteria in EM solution were not present in the manure to which the EM was added. Thus, finding the stable inoculum is necessarily required to enhance the composting process as well as the quality of its end product and this could be solved by re-inoculating the compost isolates as mentioned above. The detail of the impact of microbial inoculation on agro-industrial waste is discussed in the next section.

\section{Microbial Inoculation with Additional Functions as a Means to Enhance the Composting Process}

The impacts of microbial inoculation on the composting of various agro-industrial wastes are summarized in Table 3. Previous studies reported that inoculation of microbes into the composting led to improved mineralization [62], accelerated the composting pro- 
cess of OPEFB from 64 days to 50 days [63] and enhanced the compost maturity of rice straw and cattle manure by an increase in total nitrogen, phosphorus and potassium content [32]. The re-inoculation of microbial agents Aeromonas caviae sp. SD3 Shinella sp. XM2, Rhizobium sp. S8 Corynebacterium pseudotuberculosis sp. SD1 and Streptomyces clavuligerus sp. $\mathrm{XM}$ which were screened from rice straw compost into the composting pile accelerated the degradation of organic matter and coarse fiber content by $7.58 \%$ and $8.82 \%$, respectively due to the enhancement of key enzymes (CMCase, xylanase) and core microbial metabolisms [64]. Moreover, inoculation of a microbial inoculum consisting of Ralstonia sp. (LT703298), Penicillium sp. (LT703297), Penicillium aurantiogriseum (LT703295) and Acremonium alternatum (LT703296), with abilities for cellulose and lignin degradations improved the enzymatic activities of cellulase (15.0 to $19.8 \%$ ), urease (2.3 to $71.4 \%$ ), polyphenol oxidase activities ( 0.3 to $28.4 \%$ ) and thus, shorten the composting period and improved the maturation rate as compared to the control treatment (uninoculated) in pig manure and apple tree branch composting [65]. Henry et al. [66] reported the addition of effective microbes (EM) in the composting of chicken manure, rice bran and pine waste could enhance the population of thermophiles which consequently improved the composting rate as compared to the control composting. The finding by Wang et al. [9], showed that the inoculation of a bacterial consortia inoculant reduced the $\mathrm{C} / \mathrm{N}$, organic matter and moisture, and promotes the enrichment of Bacillus, Sphingobacterium and Saccharomonospora genus, which enhanced the pectin and cellulose degradation during the composting of citrus peel, bran and lime. Furthermore, inoculation of phosphate-solubilizing bacteria into the composting of sugarcane waste enhanced bacterial growth, mainly of the order Lactobacillales, triggering the rise of temperature at the initial phase which promoted the degradation of the lignocellulosic content and consequently enriched phosphorus content at the end of the composting [25].

Table 3. Summary of the impact of microbial inoculation on the agro-industrial waste composting by several works of literature.

\begin{tabular}{|c|c|c|c|c|c|}
\hline $\begin{array}{l}\text { Compost } \\
\text { Materials }\end{array}$ & $\begin{array}{l}\text { Inoculum/ } \\
\text { Microorganisms }\end{array}$ & $\begin{array}{l}\text { Rate of } \\
\text { Inoculum } \\
\text { Addition }\end{array}$ & $\begin{array}{l}\text { Composting } \\
\text { Conditions }\end{array}$ & $\begin{array}{l}\text { Impact on the Entire } \\
\text { Composting Process }\end{array}$ & References \\
\hline $\begin{array}{l}\text { Mushroom } \\
\text { residue }\end{array}$ & $\begin{array}{l}\text { Paenibacillus GX } 5 \\
\text { Paenibacillus GX } 7 \\
\text { Paenibacillus GX } 13 \\
\text { Brevibacillus, GX } 5 \\
\text { Brevibacillus, GX } 7 \\
\text { Brevibacillus, GX } 13\end{array}$ & $2 \mathrm{~mL} 100 \mathrm{~g}^{-1}$ & $\begin{array}{l}\mathrm{C} / \mathrm{N} \text { ratio }(12), \\
\text { Temperature } \\
\left(57^{\circ} \mathrm{C}\right), \\
\mathrm{MC}(60 \text { to } 24 \%), \\
\mathrm{pH}(8)\end{array}$ & $\begin{array}{l}\text { Improved degradation rate of } \\
\text { lignocellulose and organic } \\
\text { matter, prolonged thermophilic } \\
\text { period, enhanced microbial } \\
\text { interaction. }\end{array}$ & [19] \\
\hline $\begin{array}{l}\text { Mushroom } \\
\text { residue and } \\
\text { wood chips }\end{array}$ & $\begin{array}{l}\text { Aspergillus, Penicillium } \\
\text { Bacillus, Streptomyces }\end{array}$ & $0.2 \%\left(\mathrm{w} \mathrm{w}^{-1}\right)$ & $\begin{array}{l}\mathrm{C} / \mathrm{N} \text { ratio }(22), \\
\text { Temperature } \\
\left(58.4^{\circ} \mathrm{C}\right) \\
\mathrm{MC}(50 \%) \\
\mathrm{pH}(7.8)\end{array}$ & $\begin{array}{l}\text { Prolonged thermophilic stage, } \\
\text { increased degradation efficiency } \\
\text { of cellulose and hemicellulose, } \\
\text { optimizing the microbial } \\
\text { community structure. }\end{array}$ & [18] \\
\hline $\begin{array}{l}\text { Chicken } \\
\text { manure and } \\
\text { maize straw }\end{array}$ & $\begin{array}{l}\text { Strains isolated from } \\
\text { natural chicken manure } \\
\text { and maize straw compost: } \\
\text { Bacillus licheniformis, } \\
\text { Bacillus amyloliquefaciens, } \\
\text { Ureibacillus thermosphaericus, } \\
\text { Bacillus megaterium, } \\
\text { Geobacillus pallidus, Bacillus } \\
\text { pumilus, Geobacillus sp. } \\
\text { Paracoccus denitrificans }\end{array}$ & $\begin{array}{l}200 \mathrm{~mL} \text { with } 1 \times 10^{8} \\
\mathrm{CFU} \mathrm{mL} \mathrm{mL}^{-1} \text { cell } \\
\text { concentration }\end{array}$ & $\begin{array}{l}\mathrm{C} / \mathrm{N} \text { ratio }(21), \\
\text { Temperature } \\
\left(68.4^{\circ} \mathrm{C}\right), \\
\mathrm{MC}(55.6 \text { to } 42 \%), \\
\mathrm{pH}(8.7)\end{array}$ & $\begin{array}{l}\text { Increased germination index, } \\
\mathrm{NO}_{3} \text { content, prolonged } \\
\text { thermophilic stage, reduced } \\
\text { volatile solids contents, } \\
\text { improved humification and } \\
\text { compost maturity level. }\end{array}$ & [15] \\
\hline $\begin{array}{l}\text { Chicken } \\
\text { manure and } \\
\text { rice husk }\end{array}$ & $\begin{array}{l}\text { Ureibacillus terrenus BE8 } \\
\text { and Bacillus tequilensis BG7 }\end{array}$ & $5 \%\left(\mathrm{v} \mathrm{w}^{-1}\right)$ & $\begin{array}{l}\text { Total C }\left(263 \mathrm{~g} \mathrm{~kg}^{-1}\right) \text {, } \\
\text { and Total N } \\
\left(34 \mathrm{~g} \mathrm{~kg}^{-1}\right) \text {, } \\
\text { Temperature }\left(65^{\circ} \mathrm{C}\right) \text {, } \\
\text { MC }(78.1 \%)\end{array}$ & $\begin{array}{l}\text { Enhanced germination index } \\
\text { values, accelerated compost } \\
\text { maturity by stimulating different } \\
\text { key microbes at the initial stage } \\
\text { which promotes better } \\
\text { phytotoxicity-free compost than } \\
\text { the control treatment. }\end{array}$ & [67] \\
\hline
\end{tabular}


Table 3. Cont.

\begin{tabular}{|c|c|c|c|c|c|}
\hline $\begin{array}{l}\text { Compost } \\
\text { Materials }\end{array}$ & $\begin{array}{l}\text { Inoculum/ } \\
\text { Microorganisms }\end{array}$ & $\begin{array}{l}\text { Rate of } \\
\text { Inoculum } \\
\text { Addition }\end{array}$ & $\begin{array}{l}\text { Composting } \\
\text { Conditions }\end{array}$ & $\begin{array}{l}\text { Impact on the Entire } \\
\text { Composting Process }\end{array}$ & References \\
\hline $\begin{array}{l}\text { Pig manure } \\
\text { and wheat } \\
\text { straw }\end{array}$ & $\begin{array}{l}\text { Microbial agent solution } \\
\text { consisting of } \\
\text { photosynthetic bacteria, } \\
\text { actinomycetes, yeasts, and } \\
\text { lactic acid bacteria }\end{array}$ & $40 \mathrm{~mL} 10 \mathrm{~kg}^{-1}$ & $\begin{array}{l}\text { Total C }(41.2 \pm 0.5 \%) \\
\text { Total N }(1.79 \pm \\
0.03 \%), \text { Temperature } \\
\left(68.4^{\circ} \mathrm{C}\right), \mathrm{MC}(55 \%)\end{array}$ & $\begin{array}{l}\text { Changes in ARG profiles and } \\
\text { bacterial communities have } \\
\text { promoted the changes in the } \\
\text { potential hosts of ARGs, thus } \\
\text { increasing the removal of } \\
\text { total ARGs. }\end{array}$ & [68] \\
\hline
\end{tabular}

\begin{tabular}{|c|c|c|c|c|c|}
\hline Rice straw & $\begin{array}{l}\text { Compound bacterial agent } \\
\text { screened from rice straw } \\
\text { composts: Aeromonas caviae } \\
\text { sp. SD3 (KR868995.1), } \\
\text { Shinella sp. XM2 } \\
\text { (CP015736.1), } \\
\text { Rhizobium sp. S8 } \\
\text { (KF261556.1), } \\
\text { Corynebacterium } \\
\text { pseudotuberculosis sp. SD1 } \\
\text { (CP020356.1) and } \\
\text { Streptomyces clavuligerus sp. } \\
\text { XM (CP032052.1) }\end{array}$ & $\begin{array}{l}1 \%\left(\mathrm{w} \mathrm{w}^{-1}\right) \text { with } \\
1 \times 10^{9} \mathrm{CFU} \mathrm{\textrm {mL } ^ { - 1 }} \\
\text { cell concentration }\end{array}$ & C/N (30), MC (65\%) & $\begin{array}{l}\text { Improved the degradation of } \\
\text { organic matter and coarse fiber } \\
\text { content by } 7.58 \% \text { and, } 8.82 \% \text { due } \\
\text { to the enhancement of core } \\
\text { microbial metabolism. }\end{array}$ & {$[64]$} \\
\hline $\begin{array}{l}\text { Chicken } \\
\text { manure, rice } \\
\text { bran and pine } \\
\text { waste }\end{array}$ & $\begin{array}{l}\text { Bacteria: Bacillus spp., } \\
\text { Alicyclobacillus spp., } \\
\text { Pseudomonas spp., } \\
\text { Lactobacillus spp., } \\
\text { Pediococcuss spp., and } \\
\text { Actinomycetes. Fungi: } \\
\text { Rhizomucor pusillus, } \\
\text { Aspergillus spp. }\end{array}$ & $0.2 \%\left(\mathrm{w} \mathrm{w}^{-1}\right)$ & $\begin{array}{l}\mathrm{C} / \mathrm{N} \text { ratio }(28.4), \\
\text { Temperature }\left(65^{\circ} \mathrm{C}\right) \text {, } \\
\mathrm{MC}(60 \text { to } 40 \%), \\
\mathrm{pH}(8.5)\end{array}$ & $\begin{array}{l}\text { Increased microbial diversity } \\
\text { and population, enhanced in } \\
\text { composting rate and } \\
\text { mineralization. }\end{array}$ & [66] \\
\hline $\begin{array}{l}\text { Rice straw } \\
\text { biogas residue } \\
\text { and rice straw }\end{array}$ & $\begin{array}{l}\text { Aspergillus niger } \\
\text { CICIMF0410 and } \\
\text { P. chrysosporium AF } 96007\end{array}$ & $\begin{array}{l}1 \%\left(\mathrm{v} \mathrm{w}^{-1}\right) \text { with } \\
1 \times 10^{8} \mathrm{CFU} \mathrm{mL}^{-1} \\
\text { cell concentration }\end{array}$ & $\begin{array}{l}\mathrm{C} / \mathrm{N} \text { ratio }(32) \\
\text { Temperature } \\
\left(68.3^{\circ} \mathrm{C}\right), \mathrm{MC}(60 \%)\end{array}$ & $\begin{array}{l}\text { Reduced the time required for } \\
\text { decomposition of organic matter, } \\
\text { removed the toxicity risk for } \\
\text { crops and promoted the stability } \\
\text { of the compost. }\end{array}$ & [69] \\
\hline $\begin{array}{l}\text { Swine manure } \\
\text { and spent } \\
\text { mushroom } \\
\text { substrate }\end{array}$ & $\begin{array}{l}\text { Microbial suspension of } \\
\text { lignocellulose- } \\
\text { degrading microorganism's } \\
\text { consortium consisting of } \\
\text { Bacillus, Brevibacillus, } \\
\text { Paenibacillus and } \\
\text { Lysinibacillus genera }\end{array}$ & $10 \%\left(\mathrm{v} \mathrm{w}^{-1}\right)$ & $\begin{array}{l}\text { Mixture ratio }(1: 1) \text {, } \\
\text { Temperature } \\
\left(68^{\circ} \mathrm{C}\right), \mathrm{MC}(60 \%) \\
\mathrm{pH}(7.6)\end{array}$ & $\begin{array}{l}\text { Promoted the changes of the } \\
\text { bacterial community in the } \\
\text { mesophilic phase and reduced } \\
\text { the risk of ARGs in the final } \\
\text { compost. }\end{array}$ & [70] \\
\hline $\begin{array}{l}\text { Maize straw } \\
\text { and canola } \\
\text { residue }\end{array}$ & Phanerochaete chrysosporium & $1 \times 10^{8} \mathrm{CFU} \mathrm{mL}^{-1}$ & $\begin{array}{l}\mathrm{C} / \mathrm{N} \text { ratio }(25), \\
\text { Temperature } \\
\left(60^{\circ} \mathrm{C}\right), \mathrm{MC}(52 \%), \\
\mathrm{pH}(8.17)\end{array}$ & $\begin{array}{l}\text { Improved lignin degradation } \\
\text { during the cooling stage, } \\
\text { enhanced compost } \\
\text { humification. }\end{array}$ & [13] \\
\hline $\begin{array}{l}\text { River sediment, } \\
\text { rice straw, } \\
\text { vegetables, and } \\
\text { bran }\end{array}$ & Phanerochaete chrysosporium & $0.5 \%\left(\mathrm{v} \mathrm{w}^{-1}\right)$ & $\begin{array}{l}\mathrm{C} / \mathrm{N} \text { ratio }(30), \\
\text { Temperature } \\
\left(69^{\circ} \mathrm{C}\right), \mathrm{MC}(60 \%) \\
\mathrm{pH}(8.6)\end{array}$ & $\begin{array}{l}\text { Enhanced the passivation of } \\
\text { copper and reduced the effect of } \\
\text { pH on the bioavailability of } \\
\text { heavy metals. }\end{array}$ & {$[71]$} \\
\hline $\begin{array}{l}\text { Dairy manure } \\
\text { and sugarcane } \\
\text { leaves }\end{array}$ & $\begin{array}{l}\text { Thermophilic } \\
\text { lignocellulolytic microbes } \\
\text { screened from dairy and } \\
\text { sugarcane leaves compost } \\
\text { samples: Bacillus } \\
\text { licheniformis (TA65), } \\
\text { Aspergillus nidulans (GXU-1) } \\
\text { and Aspergillus oryzae } \\
\text { (GXU-11) }\end{array}$ & $2 \%\left(w_{w}^{-1}\right)$ & $\begin{array}{l}\mathrm{C} / \mathrm{N} \text { ratio }(30) \\
\text { Temperature } \\
\left(55^{\circ} \mathrm{C}\right)\end{array}$ & $\begin{array}{l}\text { Improve the mineralization of } \\
\text { organic carbon, promoted the } \\
\text { lignocellulose degradation and } \\
\text { the humification process. }\end{array}$ & [72] \\
\hline
\end{tabular}


Table 3. Cont.

\begin{tabular}{|c|c|c|c|c|c|}
\hline $\begin{array}{l}\text { Compost } \\
\text { Materials }\end{array}$ & $\begin{array}{l}\text { Inoculum/ } \\
\text { Microorganisms }\end{array}$ & $\begin{array}{l}\text { Rate of } \\
\text { Inoculum } \\
\text { Addition }\end{array}$ & $\begin{array}{l}\text { Composting } \\
\text { Conditions }\end{array}$ & $\begin{array}{l}\text { Impact on the Entire } \\
\text { Composting Process }\end{array}$ & References \\
\hline $\begin{array}{l}\text { Pig manure } \\
\text { and corn stalk }\end{array}$ & $\begin{array}{l}\text { Compound bacterium } \\
\text { agent comprised of } \\
\text { Acinetobacter pittii, } \\
\text { Bacillus subtilis sub sp. } \\
\text { Stercoris and Bacillus } \\
\text { altitudinis }\end{array}$ & $\begin{array}{l}1 \%\left(\mathrm{v} \mathrm{w}^{-1}\right) \text { with } \\
1 \times 10^{9} \mathrm{CFU} \mathrm{\textrm {mL } ^ { - 1 }} \\
\text { cell concentration }\end{array}$ & $\begin{array}{l}\mathrm{C} / \mathrm{N} \text { ratio }(30) \\
\text { Temperature } \\
\left(67.3^{\circ} \mathrm{C}\right), \mathrm{MC}(60 \%) \\
\mathrm{pH}(8.8)\end{array}$ & $\begin{array}{l}\text { Prolonged at the thermophilic } \\
\text { stage, decreased abundance of } \\
\text { human disease-related } \\
\text { functional genes, increased the } \\
\text { numbers of biomarkers and } \\
\text { enhanced the maturity and } \\
\text { fertility. }\end{array}$ & [73] \\
\hline $\begin{array}{l}\text { Citrus peel. } \\
\text { bran and lime }\end{array}$ & $\begin{array}{l}\text { The bacterial consortium } \\
\text { which was screened from } \\
\text { citrus peel compost samples }\end{array}$ & $3 \%\left(\mathrm{w} \mathrm{w}^{-1}\right)$ & $\begin{array}{l}\mathrm{C} / \mathrm{N} \text { ratio }(25), \\
\text { Temperature } \\
\left(65^{\circ} \mathrm{C}\right), \mathrm{MC} \\
(60 \%), \mathrm{pH}(8.5)\end{array}$ & $\begin{array}{l}\text { Decreased } \mathrm{C} / \mathrm{N} \text {, organic matter, } \\
\text { moisture, pectin and cellulose } \\
\text { content, and enhanced the } \\
\text { richness and diversity of the } \\
\text { bacterial community. }\end{array}$ & [9] \\
\hline $\begin{array}{l}\text { Cattle manure } \\
\text { and wheat } \\
\text { stalks }\end{array}$ & Bacillus subtilis & $0.5 \%\left(\mathrm{w} \mathrm{w}^{-1}\right)$ & $\begin{array}{l}\mathrm{C} / \mathrm{N} \text { ratio }(25) \\
\mathrm{MC}(60 \%), \mathrm{pH}(7.61)\end{array}$ & $\begin{array}{l}\text { Promoted changes in ARGs and } \\
\text { removed a large number of } \\
\text { pathogenic bacteria. }\end{array}$ & [74] \\
\hline $\begin{array}{l}\text { Wheat straw, } \\
\text { rice, corn and } \\
\text { soybean }\end{array}$ & $\begin{array}{l}\text { Actinomycetes: } \\
\text { Streptomyces sp. H1 } \\
\text { (KX641927.1), Mycobacerium } \\
\text { sp. G1 (KY910181.1), } \\
\text { Micromonospora sp. G7 } \\
\text { (LC333394.1) and } \\
\text { Saccha-romonospora sp. T9 } \\
\text { (NR074713.2) }\end{array}$ & $\begin{array}{l}3 \mathrm{~mL} \mathrm{~kg}^{-1} \text { with } \\
1 \times 10^{9} \mathrm{CFU} \mathrm{mL} \mathrm{mL}^{-1} \\
\text { cell concentration }\end{array}$ & $\begin{array}{l}\mathrm{C} / \mathrm{N} \text { ratio }(30), \\
\text { Temperature } \\
\left(63^{\circ} \mathrm{C}\right), \mathrm{MC}(50 \text { to } \\
60 \%), \mathrm{pH}(9.4) \text { and } \\
\text { the aeration rates: } \\
0.5 \mathrm{~L} \mathrm{~kg}^{-1} \text { (dry } \\
\text { matter) } \\
\text { min }^{-1}\end{array}$ & $\begin{array}{l}\text { Improved } 34.3 \% \text { lignocellulose } \\
\text { degradation and } 8.3 \% \text { enzyme } \\
\text { activity. }\end{array}$ & [75] \\
\hline $\begin{array}{l}\text { Pig manure } \\
\text { and apple tree } \\
\text { branches }\end{array}$ & $\begin{array}{l}\text { Microbial inoculum: } \\
\text { Ralstoinia sp., Penicillium sp., } \\
\text { Penicillium aurantiogriseum, } \\
\text { and Acremonium alternatum }\end{array}$ & $2 \%\left(\mathrm{v} \mathrm{w}^{-1}\right)$ & $\begin{array}{l}\mathrm{C} / \mathrm{N} \text { ratio }(30), \\
\text { Temperature } \\
\left(77^{\circ} \mathrm{C}\right), \\
\mathrm{MC}(60 \%), \mathrm{pH}(8.1)\end{array}$ & $\begin{array}{l}\text { Enhanced cellulase, urease, and } \\
\text { polyphenol oxidase activities } \\
\text { and promoted the succession of } \\
\text { the bacterial community } \\
\text { structure. }\end{array}$ & [65] \\
\hline $\begin{array}{l}\text { Corn straw } \\
\text { and dairy } \\
\text { manure }\end{array}$ & $\begin{array}{l}\text { Thermo-tolerant } \\
\text { actinomycetes Streptomyces } \\
\text { sp. H1, Streptomyces sp. G1, } \\
\text { Streptomyces sp. G2 and } \\
\text { Actinobacteria bacterium } \\
\text { T9 }\end{array}$ & $\begin{array}{l}2 \%\left(\mathrm{v} \mathrm{w}^{-1}\right) \text { with } \\
1 \times 10^{9} \mathrm{CFU} \mathrm{\textrm {mL } ^ { - 1 }} \\
\text { cell concentration }\end{array}$ & $\begin{array}{l}\mathrm{C} / \mathrm{N} \text { ratio }(30) \\
\text { Temperature } \\
\left(57^{\circ} \mathrm{C}\right), \mathrm{MC}(60 \%)\end{array}$ & $\begin{array}{l}\text { Enhanced cellulase activities and } \\
\text { increased degradation of } \\
\text { cellulose, humic substances } \\
\text { content. }\end{array}$ & [76] \\
\hline $\begin{array}{l}\text { Food waste } \\
\text { and maize } \\
\text { straw }\end{array}$ & $\begin{array}{l}\text { Cold adapted microbial } \\
\text { consortium comprised of } \\
\text { stains Pseudomonas fragi } \\
\text { (KY283110), } \\
\text { Pseudomonas simiae } \\
\text { (KY283111), } \\
\text { Clostridium vincentii } \\
\text { (KY283112), } \\
\text { Pseudomonas jessenii } \\
\text { (KY283113) and } \\
\text { Iodobacter fluviatilis } \\
\text { (KY283114). }\end{array}$ & $\begin{array}{l}1 \%\left(\mathrm{v} \mathrm{w}^{-1}\right) \text { with } \\
1 \times 10^{8} \mathrm{CFU} \mathrm{mL}^{-1} \\
\text { cell concentration }\end{array}$ & $\begin{array}{l}\mathrm{C} / \mathrm{N} \text { ratio }(18) \\
\text { Temperature } \\
\left(45^{\circ} \mathrm{C}\right), \mathrm{MC}(66 \%)\end{array}$ & $\begin{array}{l}\text { Increased organic matter } \\
\text { degradation at low temperature } \\
\text { and promoted the change of the } \\
\text { bacterial community } \\
\text { composition and succession. }\end{array}$ & {$[77]$} \\
\hline $\begin{array}{l}\text { Dairy manure } \\
\text { and rice straw }\end{array}$ & $\begin{array}{l}\text { Psychrotrophic- } \\
\text { thermophilic complex } \\
\text { microbial agent (PTCMA): } \\
\text { Bacillus diminuta CB1, } \\
\text { Flavobacterium glaciei CB23, } \\
\text { Aspergillus niger CF5 and } \\
\text { Penicillium commune CF8 }\end{array}$ & $\begin{array}{l}10 \mathrm{~mL} \mathrm{~kg}^{-1} \text { with } \\
1 \times 10^{8} \mathrm{CFU} \mathrm{mL} \mathrm{mL}^{-1} \\
\text { cell concentration }\end{array}$ & $\begin{array}{l}\mathrm{C} / \mathrm{N} \text { ratio }(32), \\
\text { Temperature } \\
\left(63 \text { to } 45^{\circ} \mathrm{C}\right), \\
\mathrm{MC}(60 \%), \mathrm{pH}(8.2 \text { to } \\
8.4)\end{array}$ & $\begin{array}{l}\text { Increasing the composting pile } \\
\text { temperature and significantly } \\
\text { enriched compost } \\
\text { Maturity and proposed } \\
\text { inoculation of PTCMA is an } \\
\text { effective approach in cold } \\
\text { climates. }\end{array}$ & [78] \\
\hline $\begin{array}{l}\text { Sugarcane } \\
\text { industry waste }\end{array}$ & $\begin{array}{l}\text { Phosphate-solubilizing } \\
\text { bacteria: Pseudomonas } \\
\text { aeruginosa, Bacillus sp., } \\
\text { Lactobacillales, Bacillales, } \\
\text { Pseudomonas sp., } \\
\text { Clostridiales }\end{array}$ & $\begin{array}{l}8 \mathrm{~L} \mathrm{mg}^{-1} \text { with } \\
1 \times 10^{8} \mathrm{CFU} \mathrm{mL} \mathrm{mL}^{-1} \\
\text { cell concentration }\end{array}$ & $\begin{array}{l}\mathrm{C} / \mathrm{N} \text { ratio }(30), \\
\text { Temperature } \\
\left(60^{\circ} \mathrm{C}\right)\end{array}$ & $\begin{array}{l}\text { Enhanced bacterial growth, } \\
\text { mainly of the order Lactobacillales, } \\
\text { thus causing the heating of the } \\
\text { piles during the initial phase and } \\
\text { enriched phosphorus content at } \\
\text { the end of composting. }\end{array}$ & [25] \\
\hline
\end{tabular}


Table 3. Cont.

\begin{tabular}{|c|c|c|c|c|c|}
\hline $\begin{array}{l}\text { Compost } \\
\text { Materials }\end{array}$ & $\begin{array}{l}\text { Inoculum/ } \\
\text { Microorganisms }\end{array}$ & $\begin{array}{l}\text { Rate of } \\
\text { Inoculum } \\
\text { Addition }\end{array}$ & $\begin{array}{l}\text { Composting } \\
\text { Conditions }\end{array}$ & $\begin{array}{l}\text { Impact on the Entire } \\
\text { Composting Process }\end{array}$ & References \\
\hline $\begin{array}{l}\text { Rice straw, soil, } \\
\text { vegetables, and } \\
\text { bran }\end{array}$ & Phanerochaete chrysosporium & $\begin{array}{l}2 \%\left(\mathrm{v} \mathrm{w}^{-1}\right) \text { with } \\
1 \times 10^{6} \mathrm{CFU} \mathrm{mL}^{-1} \\
\text { cell concentration }\end{array}$ & $\begin{array}{l}\mathrm{C} / \mathrm{N} \text { ratio }(30) \\
\text { Temperature } \\
\left(58^{\circ} \mathrm{C}\right), \mathrm{MC}(60 \%) \\
\mathrm{pH}(8)\end{array}$ & $\begin{array}{l}\text { Decreased the toxicity of lead } \\
\text { and increased the diversity of } \\
\text { bacterial community in the } \\
\text { composting. }\end{array}$ & [79] \\
\hline $\begin{array}{l}\text { Chicken } \\
\text { manure and } \\
\text { rice straw }\end{array}$ & $\begin{array}{l}\text { Ammonia-oxidizing } \\
\text { bacteria }\end{array}$ & $\begin{array}{l}5 \%\left(\mathrm{v} \mathrm{w}^{-1}\right) \text { with } \\
1 \times 10^{6} \mathrm{CFU} \mathrm{mL}^{-1} \\
\text { cell concentration }\end{array}$ & $\begin{array}{l}\mathrm{C} / \mathrm{N} \text { ratio }(25), \\
\text { Temperature } \\
\left(57^{\circ} \mathrm{C}\right), \mathrm{MC} \\
(60 \text { to } 70 \%), \\
\mathrm{pH}(7.4) \\
\text { aeration rate: } \\
0.5 \mathrm{~L} / \mathrm{min}\end{array}$ & $\begin{array}{l}\text { Decreased ammonia emission } \\
\text { and nitrogen loss by } \\
\text { transforming ammonium into } \\
\text { nitrite and also enhanced the } \\
\text { abundance of bacterial } \\
\text { community. }\end{array}$ & [80] \\
\hline Rice straw & $\begin{array}{l}\text { Cellulase producing } \\
\text { bacteria: Bacillus } \\
\text { licheniformis } 1-1 \mathrm{v} \text { and } \\
\text { Bacillus sonorensis } 7-1 \mathrm{v}\end{array}$ & $\begin{array}{l}1 \%\left(\mathrm{v} \mathrm{w}^{-1}\right) \text { with } \\
3.6 \text { and } 6.8 \times 10^{7} \\
\text { CFU mL } \mathrm{mL}^{-1} \text { cell } \\
\text { concentration }\end{array}$ & $\begin{array}{l}\mathrm{C} / \mathrm{N} \text { ratio }(35.8), \\
\text { Temperature } \\
\left(54^{\circ} \mathrm{C}\right), \mathrm{MC}(35 \%) \\
\mathrm{pH}(8.1)\end{array}$ & $\begin{array}{l}\text { Shortened the composting time } \\
\text { by } 40 \text { to } 43 \% \text {, resulting in a } \\
\text { higher decrease in the total } \\
\text { organic carbon and C/N ratio } \\
\text { and enriched compost quality. }\end{array}$ & [32] \\
\hline $\begin{array}{l}\text { Vegetable } \\
\text { waste: cattle } \\
\text { manure: } \\
\text { sawdust }\end{array}$ & $\begin{array}{l}\text { Phanerochaete chrysosporium } \\
\text { (MTCC 787) }\end{array}$ & $\begin{array}{l}10^{7} \text { to } 10^{8} \text { spores } g^{-1} \\
\text { of compost }\end{array}$ & $\begin{array}{l}\text { Compost mixture } \\
\text { ratio }(5: 4) \text {, } \\
\text { Temperature } \\
\left(64^{\circ} \mathrm{C}\right), \mathrm{MC}(65 \%) \\
\mathrm{pH}(7.5)\end{array}$ & $\begin{array}{l}\text { Enhanced the volatile solids } \\
\text { reduction by } 1.45 \text {-fold in trial } 2 \\
\text { (initial phase) and } 1.7 \text {-fold } \\
\text { (thermophilic phase) in trial } 3 \text { as } \\
\text { compared to uninoculated } \\
\text { compost treatment. }\end{array}$ & [81] \\
\hline $\begin{array}{l}\text { Rice straw and } \\
\text { goat manure }\end{array}$ & $\begin{array}{l}\text { EM: lactic acid bacteria, } \\
\text { yeast and phototrophic } \\
\text { bacteria. }\end{array}$ & $5 \%\left(\mathrm{v} \mathrm{w}^{-1}\right)$ & $\mathrm{C} / \mathrm{N}$ ratio $(32.4)$ & $\begin{array}{l}\text { Improved the mineralization in } \\
\text { composting process. }\end{array}$ & [62] \\
\hline $\begin{array}{l}\text { Wheat straw } \\
\text { and cattle } \\
\text { manure }\end{array}$ & $\begin{array}{l}\text { Ammonium-oxidizing } \\
\text { bacteria: Bacillaceae (strain } \\
\text { T-AOB-2, M-AOB-4 and } \\
\text { MT-AOB, 2-4) }\end{array}$ & $\begin{array}{l}5 \%\left(\mathrm{v} \mathrm{w}^{-1}\right) \text { with } \\
1 \times 10^{8} \mathrm{CFU} \mathrm{mL}^{-1} \\
\text { cell concentration }\end{array}$ & $\begin{array}{l}\mathrm{C} / \mathrm{N} \text { ratio }(30), \mathrm{MC} \\
(65 \%)\end{array}$ & $\begin{array}{l}\text { Promote formation of humic } \\
\text { substances by reducing total } \\
\text { organic carbon and dissolved } \\
\text { organic carbon, improving } \\
\text { bacterial activity. }\end{array}$ & [82] \\
\hline $\begin{array}{l}\text { Chicken } \\
\text { manure, } \\
\text { furfural } \\
\text { residues and } \\
\text { bagasse }\end{array}$ & $\begin{array}{l}\text { Exogenous microbes (VT) } \\
\text { and indigenous microbes } \\
(\mathrm{M} 3 \mathrm{~T})\end{array}$ & $0.5 \%\left(\mathrm{v} \mathrm{w}^{-1}\right)$ & $\begin{array}{l}\mathrm{C} / \mathrm{N} \text { ratio }(30), \\
\text { Temperature } \\
\left(50 \text { to } 58^{\circ} \mathrm{C}\right) \\
\mathrm{MC}(55 \%)\end{array}$ & $\begin{array}{l}\text { Improved rate of temperature } \\
\text { increase, enhanced urease, } \\
\text { protease and cellulase activity. }\end{array}$ & [83] \\
\hline $\begin{array}{l}\text { Maize straw } \\
\text { and pig } \\
\text { manure }\end{array}$ & $\begin{array}{l}\text { Bacillus subtilis, } \\
\text { Bacillus licheniformis, } \\
\text { Phanerochaete chrysosporium, } \\
\text { Trichoderma koningii, } \\
\text { Saccharomyces cerevisiae }\end{array}$ & $0.1 \%\left(\mathrm{w} \mathrm{w}^{-1}\right)$ & $\begin{array}{l}\mathrm{C} / \mathrm{N} \text { ratio }(27.7) \\
\text { Temperature } \\
\left(66^{\circ} \mathrm{C}\right), \mathrm{MC}(60 \%)\end{array}$ & $\begin{array}{l}\text { Improved rate of temperature } \\
\text { increase, increased } \\
\text { micronutrients }(\mathrm{N}, \mathrm{P}, \mathrm{K}) \text {, } \\
\text { enhanced decomposition of } \\
\text { organic carbon, improved } \\
\text { germination index. }\end{array}$ & [84] \\
\hline $\begin{array}{l}\text { Wheat straw } \\
\text { and dairy } \\
\text { manure }\end{array}$ & $\begin{array}{l}\text { Microbial agent: } \\
\text { Aspergillus niger, } \\
\text { Saccharomyces cerevisiae, } \\
\text { Lactobacillus plantarum, } \\
\text { Lactobacillus acidophilus, } \\
\text { Bacillus megaterium, } \\
\text { Streptomyces albogriseus and } \\
\text { Bacillus subtilis }\end{array}$ & $0.2 \%\left(\mathrm{v} \mathrm{w}^{-1}\right)$ & $\begin{array}{l}\mathrm{C} / \mathrm{N} \text { ratio }(16), \\
\text { Temperature } \\
\left(60^{\circ} \mathrm{C}\right), \mathrm{MC}(60 \%), \\
\mathrm{pH}(8.0)\end{array}$ & $\begin{array}{l}\text { Increased composting maturity } \\
\text { and total organic carbon } \\
\text { degradation, decreased } \\
\text { abundance of potential } \\
\text { pathogen and improved key } \\
\text { bacterial network interaction. }\end{array}$ & [85] \\
\hline $\begin{array}{l}\text { Rice straw and } \\
\text { cattle manure }\end{array}$ & $\begin{array}{l}\text { Malbranchea cinnamonmea, } \\
\text { Gloephyllum } \\
\text { trabeum }\end{array}$ & $10 \mathrm{~mL} \mathrm{~kg}^{-1}$ & $\begin{array}{l}\mathrm{C} / \mathrm{N} \text { ratio }(25), \\
\text { Temperature } \\
\left(73^{\circ} \mathrm{C}\right), \mathrm{MC}(65 \%), \\
\mathrm{pH}(8.5)\end{array}$ & $\begin{array}{l}\text { Promoted cellulose, } \\
\text { hemicellulose and lignin } \\
\text { degradation, increased nutrients } \\
\text { and humus carbon, increased } \\
\text { diversity and relative abundance } \\
\text { of lignocellulosic fungi. }\end{array}$ & [86] \\
\hline
\end{tabular}


Table 3. Cont.

\begin{tabular}{|c|c|c|c|c|c|}
\hline $\begin{array}{l}\text { Compost } \\
\text { Materials }\end{array}$ & $\begin{array}{l}\text { Inoculum/ } \\
\text { Microorganisms }\end{array}$ & $\begin{array}{l}\text { Rate of } \\
\text { Inoculum } \\
\text { Addition }\end{array}$ & $\begin{array}{l}\text { Composting } \\
\text { Conditions }\end{array}$ & $\begin{array}{l}\text { Impact on the Entire } \\
\text { Composting Process }\end{array}$ & References \\
\hline $\begin{array}{l}\text { Rice straw and } \\
\text { swine manure }\end{array}$ & $\begin{array}{l}\text { Kitasatospora phosalacinea C1, } \\
\text { Paenibacillus glycanilyticus } \\
\mathrm{X} 1 \text {, Bacillus licheniformis S3, } \\
\text { Brevibacillus agri E4 and } \\
\text { Phanerochaete chrysosporium }\end{array}$ & Not mentioned & $\begin{array}{l}\mathrm{C} / \mathrm{N} \text { ratio }(27.5), \\
\text { Temperature } \\
\left(62^{\circ} \mathrm{C}\right)\end{array}$ & $\begin{array}{l}\text { Improved rate of temperature } \\
\text { increase, enhanced } \\
\text { maturation level. }\end{array}$ & [87] \\
\hline $\begin{array}{l}\text { Wheat straw } \\
\text { and swine } \\
\text { manure }\end{array}$ & Gloephyllum trabeum & $\begin{array}{l}1 \times 10^{8} \text { spores } \\
\mathrm{kg}^{-1}\end{array}$ & $\begin{array}{l}\mathrm{C} / \mathrm{N} \text { ratio }(27), \\
\text { Temperature } \\
\left(73^{\circ} \mathrm{C}\right), \mathrm{MC}(60 \%)\end{array}$ & $\begin{array}{l}\text { Shorten maturation period, } \\
\text { increased decomposition rate of } \\
\text { cellulose, hemicellulose and } \\
\text { lignin, influencing fungal } \\
\text { community by increasing } \\
\text { relative abundance of Aspergillus, } \\
\text { Mycothemus and melanocapus. }\end{array}$ & [88] \\
\hline
\end{tabular}

Note: MC (Moisture content).

Another finding by Wan et al. [15] revealed that the addition of a microbial cocktail inoculum consisting of Bacillus licheniformis, Bacillus amyloliquefaciens, Bacillus megaterium, Bacillus pumilus, Geobacillus pallidus, Ureibacillus thermosphaericus and Paracoccus denitrificans which were isolated and cultivated from chicken manure and maize straw compost itself enhanced the thermophilic phase of composting process with maximum temperature reaching $68{ }^{\circ} \mathrm{C}$ as compared to the control treatment with only $60.8^{\circ} \mathrm{C}$ as the maximum temperature. Due to this, the germination index increases as high temperature reduced the phytotoxicity effect and thus contributed to the better maturity level of the compost [89]. Previously, Zhang et al. [80] reported the inoculation of enriched ammonia-oxidizing bacteria successfully reduced ammonia emission by $53 \%$ of total ammonia than uninoculated compost by promoting ammonia transformation into nitrate. The inoculation of combined bacterial agents (Acinetobacter pittii, Bacillus subtilis sub sp. Stercoris and Bacillus altitudinis) influenced the bacterial community succession and prolonged the thermophilic stage of the composting of pig manure and corn stalk by 2 days [73]. The inoculation of these microbes also increased the total phosphorus and showed no plant toxicity at the end of the composting process. Their findings showed that the extended thermophilic period reduced the abundance of human disease-related functional genes which was due to the elimination of a large number of pathogenic bacteria.

Liu et al. [67] reported that the germination index of the chicken manure and rice husk composting reached $80 \%$ within 13 days with the addition of microbial inoculants as compared to control which took 21 days to reach this value. The higher GI achieved was attributed to the increase in fluorescence intensity of fulvic acid-like and humic acid-like substances detected, indicating inoculation of microbes promotes the biotransformation of water-extractable organic matter and also the compost maturity. Zhang et al. [90] suggested that compost with more than $80 \%$ GI could be considered as matured and phytotoxicity-free. Similarly, inoculation of Phanerochaete chrysosporium at the cooling phase of the composting of maize straw and canola residues showed the higher GI (103.11\%) as compared to the control (without inoculation) and inoculation at the initial phase with GI at only $90.65 \%$ and $96 \%$, respectively [13].

To date, fungal inoculation had shown its effectiveness for enhancing the composting process. One of the significant and widely used fungi in composting is white-rot fungus Phanerochaete chrysosporium that produces the extracellular enzymes system consisting of manganese peroxidase, lignin peroxidase and laccases for lignocellulose degradation [81]. Huang et al. [79] demonstrated that inoculation with Phanerochaete chrysosporium significantly reduced the toxicity in the composting of lead $(\mathrm{Pb})$-contaminated rice straw, soil, vegetables and bran. Likewise, via DGGE profile analysis, Phanerochaete chrysosporium showed a positive impact on the bacterial community composition which contributed to the reduction of toxic $\mathrm{Pb}^{2+}$ ions concentration. A study by Chen et al. [71] also showed that the inocula- 
tion of Phanerochaete chrysosporium reduced the bioavailability of heavy metals for cadmium, plumbum and zinc, respectively, as compared to non-inoculated composting of agricultural waste and river sediment. This is due to the fact that Phanerochaete chrysosporium promotes the passivation of heavy metals through chelation action by organic humus. It was also found that the inoculation with Phanerochaete chrysosporium showed greater passivation of copper than other heavy metals during the composting process.

Furthermore, the inoculation of Phanerochaete chrysosporium at the initial and thermophilic stages in the co-composting of vegetable waste, cattle manure and sawdust at ratio 5:4:1 promoted the volatile solids reduction by 1.45-fold (initial phase) and 1.7-fold (thermophilic phase) as compared to the uninoculated compost treatment [81]. Wan et al. [15] reported the inoculation of microbial cocktails in the composting pile also improved the reduction of volatile solids from initial content of $44 \%$ in both piles to final content of $29.9 \%$ for the inoculation and $32.1 \%$ for the control treatment. The reduction of the volatile solids was mainly due to the volatilization of ammonia gases during the composting process [91]. Additionally, the combination of Aspergillus niger and Phanerochaete chrysosporium reduced the composting time by improving the degradation rates of hemicellulose, cellulose and lignin by $29.4 \%, 34.8 \%$ and $40.5 \%$, respectively, as compared to the control treatment [69]. Moreover, the inoculation of both fungi promoted the maturity level of compost through the enhancement of humification with higher humic acid content (10.5\% to $18.6 \%)$ and humification index (1.69 to 2.64) in 30 days of the composting process. Another finding by $\mathrm{Xu}$ et al. [72] revealed the degradation rate of cellulose and hemicellulose for inoculated dairy manure-sugarcane leaves composting (27\%) was higher than that of the uninoculated composting $(22 \%)$. Inoculation also promoted the formation of humic substance compost by $11.82 \%$ higher than that of the uninoculated one. Hence, $\mathrm{Xu}$ et al. [92] concluded that the inoculation of efficient microbes could enhance the metabolism of easily available organic compounds and the organic matter of the composting process. In addition, Wei et al. [75] revealed that the inoculation of actinomycetes in the composting of wheat, rice, corn and soybean straw improved by $34.3 \%$ lignocellulose degradation and by $8.3 \%$ enzyme activity. These results were in agreement with the studies reported by Zeng et al. [93] which demonstrated that with the inoculation of Phanerochaete chrysosporium during the mesophilic cooling phase of the composting of agricultural wastes (mixture of rice straw, vegetables, rice bran and soil) enhanced the xylanase, manganese peroxidase and lignin peroxidase activity which then increased by $40 \%$ lignocellulose degradation ratio. Similarly, thermotolerant cellulolytic actinomycetes (Streptomyces sp. H1, Streptomyces sp. G1, Streptomyces sp. G2 and Actinobacteria bacterium) which were inoculated into different (initial, thermophilic and cooling) stages of composting were reported to enrich cellulase activities, enhance the degradation of cellulose, increase the content of the humic substances and subsequently influence the structure of the actinomycete community in dairy manure-corn straw composting [76].

In general, composting is conducted in an environment with ambient temperatures between $20{ }^{\circ} \mathrm{C}$ to $30{ }^{\circ} \mathrm{C}$. However, in cold climates conditions such as winter with temperatures usually lower than $15^{\circ} \mathrm{C}$, it is difficult to operate the composting process due to the slow metabolism of microbes that contributes to the suppression of microbial heat generation in the piles [94]. As a solution, the inoculation of cold-adapted and thermophilic microbial agents consisting of Brevundimonas diminuta CB1, Flavobacterium glaciei CB23, Aspergillus versicolor CF5 and Penicillium commune CF8 successfully increased the temperature at the onset of composting and significantly improved the compost maturity by decreasing the total organic carbon and $\mathrm{C} / \mathrm{N}$ ratios, as well as promoting the increment of total nitrogen, degradation of cellulose and lignin, and germination index than the control compost [78]. This was in agreement with Xie et al. [77] who showed that the inoculation of a cold-adapted microbial consortium consisting of strains Pseudomonas fragi (KY283110), Pseudomonas simiae (KY283111), Clostridium vincentii (KY283112), Pseudomonas jessenii (KY283113) and Iodobacter fluviatilis (KY283114) significantly enhanced the degradation of organic matter and increased the temperature when the food waste was composted 
at low ambient temperature $\left(10{ }^{\circ} \mathrm{C}\right)$, contributing to start-up composting in winter or cold regions.

It is also important to highlight that, composting is regarded as an effective method to eliminate antibiotic resistance genes (ARGs) present in the waste especially manure. Manure application has been shown to increase the occurrence and spread of ARG in soils that may enter the food chain via contaminated crops and groundwater, hence, posing a potential risk to human health [95]. As reported by Cao et al. [68] the addition of microbial agents composed of photosynthetic bacteria, actinomycetes, yeasts and lactic acid bacteria in the composting increased the reduction of total ARGs by changing the variations of ARG profiles and the potential hosts of ARGs (bacterial community) which subsequently influences the removal of ARGs. Similarly, the inoculation of $0.5 \%(\mathrm{w} / \mathrm{w})$ of Bacillus subtilis into the composting of cattle manure and wheat stalks mixture decreased the relative abundances of ARGs, mobile genetic elements and human pathogenic bacteria (by 2 to $3 \operatorname{logs}$ ) in the composts [74]. Furthermore, it was reported that the inoculation of microbial suspension of lignocellulose-degrading microorganisms consisting of mainly Bacillus, Brevibacillus, Paenibacillus and Lysinibacillus genera, decreased the total relative abundance of ARGs by 0.08 logs and affected the bacterial community structure in the mesophilic phase, with the inhibitory effect of potential pathogens during the composting of swine manure and spent mushroom substrate as compared to control treatment [70]. Hence, the addition of inoculum could potentially reduce the ARGs, inhibit pathogens, as well as making the final compost products safer.

Although microbial inoculation has demonstrated some outstanding effects on the composting process, the economic feasibility of this technology should be considered so that it could be applied at the pilot or large-scale production levels. Many of the success stories of this technology are mainly based on small-scale production. As far as we know, there is only a study done by Yoshizaki et al. [96], who evaluated the economic viability of composting of an agro-industrial waste, oil palm biomass which is oil palm empty fruit bunch (OPEFB), with sludge containing microbial seeds at the semi-industrial and commercial-scale production in Malaysia. In this study, the palm oil mill effluent (POME) anaerobic sludge from the anaerobic digestor and OPEFB were used as the composting material. Their findings showed that the composting of 11,570 tons of EFB and POME anaerobic sludge produced 579 tons of nitrogen, 151 tons of phosphorus and 761 tons of potassium per year. It was estimated that the produced compost could provide a $32 \%$ internal rate of return (IRR) of USD 9.53 million of net present value (NPV) and 2.9 years for the payback period (PBP) of the investment in 10 years. However, the economic analysis of composting with raw POME showed that the IRR, NPV and PBP for 10 years were $8 \%$, USD 0.43 million and 6.5 years, respectively, which is $24 \%$ and USD 9.1 million less and 3.6 years longer than that of composting with POME anaerobic sludge. The results indicated that composting with POME anaerobic sludge was more effective as compared to composting with raw POME. The reason might be that the raw POME did not provide enough microbial seeding and nutrient resources, owing to its diverse characteristics. Unlike raw POME, POME anaerobic sludge generated from the anaerobic digester demonstrated higher nutritional and microbial seed contents with consistent characteristics. Therefore, the higher IRR and faster PBP could be due to the enhancement of the composting process through the application of palm oil mill effluent anaerobic sludge consisting of not only nutrients but also various beneficial indigenous microorganisms which reduced the degradation time, from 60 days to 40 days, with acceptable quality and maturity of the composting product $[30,56]$. The microbial seed present in the POME anaerobic sludge made this material highly applicable and economically viable as no additional microbes and enzymes were required in order to maintain the quality of the product. It is important to note that the supplementation of single or multiple microbes and enzymes would contribute to the additional annual cost of operations and maintenance. Therefore, developing the optimal methods of microbial seeding is required to ensure that this technology is economically viable especially in pilot or industrial-scale production. In addition, several bacterial strains 
including Citrobacter sidlakii and Bacillus tequilensis with multiple functions such as plant growth promotion, biocontrol and lignocellulose degradation were successfully isolated from the OPFEB-POME anaerobic sludge compost [97]. Therefore, the produced OPFEBPOME anaerobic sludge compost can be a prodigious replacement for mineral fertilizer as it contains not only high nutrient content, but also a beneficial microbe that is good for soil amendments and crop growth. As a result, the cost for feedstock of the composting process and chemical/inorganic fertilizer could be cut down significantly with the application of composts. Yoshizaki et al. [96] also pointed out that the OPEFB-POME anaerobic sludge compost can replace around 3250 tons of the conventional chemical fertilizer used to fertilize the palm tree in the plantation.

\section{Future Perspectives and Recommendations}

As discussed above, the addition of microorganisms into the composting system is considered a valuable and interesting approach to treat agro-industrial waste. However, there are still limitations and challenges of developing a cost-effective methodology that is both economically and environmentally sustainable. In this section, we highlighted some perspectives as guidance for future investigations:

1. The question of what is the appropriate technique of microbial inoculation to achieve a better composting process persists. In particular, it is difficult to establish what is the suitable concentration of a single or mixed inoculant to be added to the composting mixture. The optimum microbial concentration is still yet to be determined. In addition, the types of inoculants, functional, physiology, adaptability and stability of the microbes during the composting process also need to be considered. Therefore, research aimed at the microbial mechanism is required in order to find the most suitable microbial inoculants to be added during the composting process.

2. There still exists significant knowledge gaps about the composting process enhancements through inoculation. For instance, based on the current literature search, there is limited research available dealing with the production of compost from agro-industrial waste, particularly at the semi-industrial or commercial scale. In comparison to the small or laboratory scale, it is difficult to control the composting in large-scale production since it is a self-heating and solid-state fermentation process, which hinders the replicability or reproducibility of the process. Thus, more studies on microbial inoculations at the semi-industrial or commercial scale need to be carried out for all types of composting systems such as the aerated static pile and the in-vessel system to validate the repeatability and advantages reported in small-scale studies.

3. It is necessary to develop the technological procedures for the production of inoculants so that they are economically viable because growing microbes in the bioreactor submerge fermentation may be costly at the pilot or commercial scale. The solution such as the use of waste or low-cost materials such as molasses, sago and lignocellulose hydrolysate for propagating the inoculant should be developed to reduce the cost of production.

4. Research in modeling and optimization for all composting systems by the engineering processing technique would be required in order to build up and sustain the overall composting process without compromising the quality of the composting product. Studies on significant statistical correlations should be carried out between the dynamics of microbial inoculants and important factors such as temperature, oxygen level, moisture and $\mathrm{pH}$ at different composting stages for monitoring the process. The effects of microbial inoculum on the indigenous microbial community in the composting pile should also be analyzed and recorded.

5. The monitoring of microbial inoculants is also required to ensure the survival of inoculants and their impact on indigenous microbes throughout the composting process. The monitoring of microbial community structure during the composting process can be done through the use of culture-independent methods such as PCRDGGE, high-throughput $16 \mathrm{~S}$ rRNA sequencing. 


\section{Conclusions}

The introduction of numerous effective microorganisms into the composting process has a wide range of favorable effects. Various inoculation strategies, such as inoculation of a single or mixed microbial culture, and the addition of inoculants at different stages, can be used to improve the agricultural waste composting process. These strategies have a substantial influence on the composting productivity such as organic matter degradation, humification temperature, enzyme activity, microbial population, and the quality of its end products such as germination index. It is noteworthy to demonstrate that the addition of sludge containing microbial consortium seed can improve the composting process of oil palm biomass waste and is possible on the semi-commercial and industrial scales. However, more research is needed to fully understand the mechanisms of microbial inoculation's effects on composting as well as to explore the relationships between the microbial inoculum, the composting pile, the indigenous microbial community, and the composting processes at both the pilot scale and the industrial scales. This review may be beneficial as a guideline for the application of appropriate and effective microbial inoculants for the composting process improvement based on the type of agricultural waste material.

Author Contributions: Conceptualization, M.H.M.Z. and K.S.; investigation, M.H.M.Z., A.Z., A.S.A., S.M. and K.S.; resources, M.H.M.Z., A.Z., A.S.A. and S.M.; writing-original draft preparation, M.H.M.Z., A.Z., A.S.A. and S.M.; writing-review and editing, M.H.M.Z. and A.Z.; visualization, K.S.; supervision, M.A.H. and Y.S.; All authors have read and agreed to the published version of the manuscript.

Funding: This work received no external funding for publication.

Institutional Review Board Statement: Not applicable.

Informed Consent Statement: Not applicable.

Data Availability Statement: No new data were created or analyzed in this study. Data sharing is not applicable to this article.

Acknowledgments: This work was sponsored and supported by a research collaboration project between FELDA, Universiti Putra Malaysia (UPM), and Kyushu Institute of Technology, Japan. The authors would like to thank the Ministry of Higher Education, Malaysia for granting the Institute of Tropical Agriculture and Food Security (ITAFoS), Universiti Putra Malaysia, with a Higher Education Centre of Excellence (HICoE) status.

Conflicts of Interest: The authors declare no conflict of interest.

\section{References}

1. The World Bank Group World Development Indicators: Structure of Output. 2020. Available online: http://wdi.worldbank.org/ table/4.2 (accessed on 24 February 2020).

2. Food and Agriculture Organization of the United Nations. World Crop Production. 2022. Available online: http://www.fao.org/ faostat/en/\#data/QC (accessed on 16 November 2021).

3. Bilal, M.; Asgher, M.; Iqbal, H.M.N.; Hu, H.; Zhang, X. Biotransformation of lignocellulosic materials into value-added productsA review. Int. J. Biol. Macromol. 2017, 98, 447-458. [CrossRef] [PubMed]

4. Al-Suhaibani, N.; Selim, M.; Alderfasi, A.; El-Hendawy, S.; Selim, M. Comparative performance of integrated nutrient management between composted agricultural wastes, chemical fertilizers, and biofertilizers in improving soil quantitative and qualitative properties and crop yields under arid conditions. Agronomy 2020, 10, 1503. [CrossRef]

5. Ghosh Ray, S.; Ghangrekar, M.M. Comprehensive review on treatment of high-strength distillery wastewater in advanced physico-chemical and biological degradation pathways. Int. J. Environ. Sci. Technol. 2019, 16, 527-546. [CrossRef]

6. Lim, S.L.; Lee, L.H.; Wu, T.Y. Sustainability of using composting and vermicomposting technologies for organic solid waste biotransformation: Recent overview, greenhouse gases emissions and economic analysis. J. Clean. Prod. 2016, 111, 262-278. [CrossRef]

7. Fan, Y.V.; Lee, C.T.; Ho, C.S.; Klemeš, J.J.; Wahab, R.A.; Chua, L.S.; Sarmidi, M.R. Evaluation of microbial inoculation technology for composting. Chem. Eng. Trans. 2017, 56, 433-438. [CrossRef]

8. Toledo, M.; Siles, J.A.; Gutiérrez, M.C.; Martín, M.A. Monitoring of the composting process of different agroindustrial waste: Influence of the operational variables on the odorous impact. Waste Manag. 2018, 76, 266-274. [CrossRef] [PubMed] 
9. Wang, J.; Liu, Z.; Xia, J.; Chen, Y. Effect of microbial inoculation on physicochemical properties and bacterial community structure of citrus peel composting. Bioresour. Technol. 2019, 291, 121843. [CrossRef] [PubMed]

10. Lin, L.; Xu, F.; Ge, X.; Li, Y. Improving the sustainability of organic waste management practices in the food-energy-water nexus: A comparative review of anaerobic digestion and composting. Renew. Sustain. Energy Rev. 2018, 89, 151-167. [CrossRef]

11. Huang, H.L.; Zeng, G.M.; Luo, L.; Zhang, J.C.; Yu, M.; Qin, P.F. Effect of inoculation during different phases of agricultural waste composting on spectroscopic characteristics of humic acid. J. Cent. South Univ. 2015, 22, 4177-4183. [CrossRef]

12. Ngoc, Q.; Tran, M.; Mimoto, H.; Nakasaki, K. Inoculation of lactic acid bacterium accelerates organic matter degradation during composting. Int. Biodeterior. Biodegrad. 2015, 104, 377-383. [CrossRef]

13. Chen, Y.; Wang, Y.; Xu, Z.; Liu, Y.; Duan, H. Enhanced humification of maize straw and canola residue during composting by inoculating Phanerochaete chrysosporium in the cooling period. Bioresour. Technol. 2019, 293, 122075. [CrossRef]

14. Li, C.; Li, H.; Yao, T.; Su, M.; Li, J.; Liu, Z.; Xin, Y.; Wang, L.; Chen, J.; Gun, S. Effects of microbial inoculation on enzyme activity, available nitrogen content, and bacterial succession during pig manure composting. Bioresour. Technol. 2020, 306, 123-167. [CrossRef] [PubMed]

15. Wan, L.; Wang, X.; Cong, C.; Li, J.; Xu, Y.; Li, X.; Hou, F. Effect of inoculating microorganisms in chicken manure composting with maize straw. Bioresour. Technol. 2020, 301, 122730. [CrossRef] [PubMed]

16. Sánchez, Ó.J.; Ospina, D.A.; Montoya, S. Compost supplementation with nutrients and microorganisms in composting process. Waste Manag. 2017, 69, 136-153. [CrossRef] [PubMed]

17. Sanchez-Monedero, M.A.; Cayuela, M.L.; Roig, A.; Jindo, K.; Mondini, C.; Bolan, N. Role of biochar as an additive in organic waste composting. Bioresour. Technol. 2018, 247, 1155-1164. [CrossRef] [PubMed]

18. Jia, X.; Qin, X.; Tian, X.; Zhao, Y.; Yang, T.; Huang, J. Inoculating with the microbial agents to start up the aerobic composting of mushroom residue and wood chips at low temperature. J. Environ. Chem. Eng. 2021, 9, 105294. [CrossRef]

19. Zhao, Y.; Zhuge, C.; Weng, Q.; Hu, B. Additional strains acting as key microbes promoted composting process. Chemosphere 2022, 287, 132304. [CrossRef]

20. Vallejos, M.E.; Felissia, F.E.; Area, M.C. Hydrothermal treatments applied to agro- and forest-industrial waste to produce high added-value compounds. BioResources 2016, 12, 2058-2080. [CrossRef]

21. Yusuf, M. Agro-industrial waste materials and their recycled value added applications: Review. In Handbook of Ecomaterials; Springer International Publishing: New York, NY, USA, 2017; pp. 1-11. ISBN 9783319482811.

22. Sadh, P.K.; Duhan, S.; Duhan, J.S. Agro-industrial wastes and their utilization using solid state fermentation: A review. Bioresour Bioprocess. 2018, 5, 1-15. [CrossRef]

23. Singh, R.; Das, R.; Sangwan, S.; Rohatgi, B.; Khanam, R.; Peera, S.K.P.G.; Das, S.; Lyngdoh, Y.A.; Langyan, S.; Shukla, A.; et al. Utilisation of agro-industrial waste for sustainable green production: A review. Environ. Sustain. 2021, 4, 619-636. [CrossRef]

24. Hassan, M.A.; Ahmad Farid, M.A.; Shirai, Y.; Ariffin, H.; Othman, M.R.; Samsudin, M.H.; Hasan, M.Y. Oil palm biomass biorefinery for sustainable production of renewable materials. Biotechnol. J. 2019, 14, 1800394. [CrossRef] [PubMed]

25. Estrada-Bonilla, G.A.; Lopes, C.M.; Durrer, A.; Alves, P.R.L.; Passaglia, N.; Cardoso, J.B.N. Effect of phosphate-solubilizing bacteria on phosphorus dynamics and the bacterial community during composting of sugarcane industry waste. Syst. Appl. Microbiol. 2017, 40, 308-313. [CrossRef] [PubMed]

26. Tahir, P.; Liew, W.; Yih, S.; Fei, A.; Hua, S. Diversity and characterization of lignocellulolytic fungi isolated from oil palm empty fruit bunch, and identification of influencing factors of natural composting process. Waste Manag. 2020, 100, 128-137. [CrossRef] [PubMed]

27. Trisakti, B.; Mhardela, P.; Husaini, T.; Irvan; Daimon, H. Production of oil palm empty fruit bunch compost for ornamental plant cultivation. IOP Conf. Ser. Mater. Sci. Eng. 2018, 309, 012094. [CrossRef]

28. Irvan; Husaini, T.; Trisakti, B.; Batubara, F.; Daimon, H. Composting of empty fruit bunches in the tower composter-effect of air intake holes. IOP Conf. Ser. Mater. Sci. Eng. 2018, 309, 012066. [CrossRef]

29. Siddiquee, S.; Shafawati, S.N.; Naher, L. Effective composting of empty fruit bunches using potential Trichoderma strains. Biotechnol. Rep. 2017, 13, 1-7. [CrossRef]

30. Zainudin, M.H.M.; Ramli, N.; Hassan, M.A.; Shirai, Y.; Tashiro, K.; Sakai, K.; Tashiro, Y. Bacterial community shift for monitoring the co-composting of oil palm empty fruit bunch and palm oil mill effluent anaerobic sludge. J. Ind. Microbiol. Biotechnol. 2017, 44, 869-877. [CrossRef]

31. Latifah, O.; Ahmed, O.H.; Susilawati, K.; Majid, N.M. Compost maturity and nitrogen availability by co-composting of paddy husk and chicken manure amended with clinoptilolite zeolite. Waste Manag. Res. 2015, 33, 322-331. [CrossRef]

32. Abdel-Rahman, M.A.; El-din, M.N.; Refaat, B.M.; Abdel-shakour, E.H.; Ewais, E.E.; Alrefaey, H.M.A. Biotechnological application of thermotolerant cellulose-decomposing bacteria in composting of rice straw. Ann. Agric. Sci. 2016, 61, 135-143. [CrossRef]

33. Gaind, S. Effect of fungal consortium and animal manure amendments on phosphorus fractions of paddy-straw compost. Int. Biodeterior. Biodegrad. 2014, 94, 90-97. [CrossRef]

34. Devi, S.; Sharma, C.R.; Singh, K. Microbiological biodiversity in poultry and paddy straw wastes in composting systems. Braz. J. Microbiol. 2012, 43, 288-296. [CrossRef]

35. Dadi, D.; Daba, G.; Beyene, A.; Luis, P.; Van der Bruggen, B. Composting and co-composting of coffee husk and pulp with source-separated municipal solid waste: A breakthrough in valorization of coffee waste. Int. J. Recycl. Org. Waste Agric. 2019, 8 , 263-277. [CrossRef] 
36. Getachew, G.; Muleta, D. Optimization of compost maturity of coffee waste mixed with agricultural wastes and evaluation of their effect on growth of lettuce (Lactuca Sativa). Nat. Sci. Res. 2017, 7, 82-92.

37. Calabi-floody, M.; Medina, J.; Suazo, J.; Ordiqueo, M.; Aponte, H.; Mora, D.L.L.M.; Rumpel, C. Optimization of wheat straw co-composting for carrier material development. Waste Manag. 2019, 98, 37-49. [CrossRef] [PubMed]

38. Zhou, G.; Qiu, X.; Chen, L.; Zhang, C.; Ma, D.; Zhang, J. Succession of organics metabolic function of bacterial community in response to addition of earthworm casts and zeolite in maize straw composting. Bioresour. Technol. 2019, 280, 229-238. [CrossRef]

39. Zhang, L.; Ma, H.; Zhang, H.; Xun, L.; Chen, G.; Wang, L. Thermomyces lanuginosus is the dominant fungus in maize straw composts. Bioresour. Technol. 2015, 197, 266-275. [CrossRef]

40. Meng, L.; Zhang, S.; Gong, H.; Zhang, X.; Wu, C.; Li, W. Improving sewage sludge composting by addition of spent mushroom substrate and sucrose. Bioresour. Technol. 2018, 253, 197-203. [CrossRef]

41. Lou, Z.; Sun, Y.; Zhou, X.; Baig, S.A.; Hu, B.; Xu, X. Composition variability of spent mushroom substrates during continuous cultivation, composting process and their effects on mineral nitrogen transformation in soil. Geoderma 2017, 307, 30-37. [CrossRef]

42. Erana, F.G.; Tenkegna, T.A.; Asfaw, S.L. Effect of agro industrial wastes compost on soil health and onion yields improvemepnts: Study at field condition. Int. J. Recycl. Org. Waste Agric. 2019, 8, 161-171. [CrossRef]

43. Patil, M.G.; Rathod, P.K.; Patil, V.D. Compost: A tool for managing soil borne plant pathogens. Int. J. Curr. Microbiol. Appl. Sci. 2018, 6, 272-280.

44. Mehta, C.M.; Palni, U.; Franke-Whittle, I.H.; Sharma, A.K. Compost: Its role, mechanism and impact on reducing soil-borne plant diseases. Waste Manag. 2014, 34, 607-622. [CrossRef]

45. Chandini, K.R.; Kumar, R.; Prakash, O. The impact of chemical fertilizers on our environment and ecosystem. In Research Trends in Environmental Sciences; AkiNik Publications: Delhi, India, 2019; pp. 69-86.

46. Zhao, J.; Ni, T.; Li, J.; Lu, Q.; Fang, Z.; Huang, Q.; Zhang, R.; Li, R.; Shen, B.; Shen, Q. Effects of organic-inorganic compound fertilizer with reduced chemical fertilizer application on crop yields, soil biological activity and bacterial community structure in a rice-wheat cropping system. Appl. Soil Ecol. 2016, 99, 1-12. [CrossRef]

47. Latifah, O.; Ahmed, O.H.; Majid, N.M.A. Enhancing nutrients use efficiency and grain yield of Zea mays L. Cultivated on a tropical acid soil using paddy husk compost and clinoptilolite zeolite. Bulg. J. Agric. Sci. 2017, 23, 418-428.

48. Berecha, G.; Lemessa, F.; Wakjira, M. Exploring the suitability of coffee pulp compost as growth media substitute in greenhouse production. Int. J. Agric. Res. 2011, 6, 255-267. [CrossRef]

49. Yadav, K.S.; Mishra, M.M.; Kapoor, K.K. The effect of fungal inoculation on composting. Agric. Wastes 1982, 4, 329-333. [CrossRef]

50. Faure, D.; Deschamps, A.M. The effect of bacterial inoculation on the initiation of composting of grape pulps. Bioresour. Technol. 1991, 37, 235-238. [CrossRef]

51. Xi, B.D.; He, X.S.; Wei, Z.M.; Jiang, Y.H.; Li, M.X.; Li, D.; Li, Y.; Dang, Q.L. Effect of inoculation methods on the composting efficiency of municipal solid wastes. Chemosphere 2012, 88, 744-750. [CrossRef]

52. Xi, B.; He, X.; Dang, Q.; Yang, T.; Li, M.; Wang, X.; Li, D.; Tang, J. Effect of multi-stage inoculation on the bacterial and fungal community structure during organic municipal solid wastes composting. Bioresour. Technol. 2015, 196, 399-405. [CrossRef] [PubMed]

53. Zeng, G.M.; Huang, H.L.; Huang, D.L.; Yuan, X.Z.; Jiang, R.Q.; Yu, M.; Yu, H.Y.; Zhang, J.C.; Wang, R.Y.; Liu, X.L. Effect of inoculating white-rot fungus during different phases on the compost maturity of agricultural wastes. Process Biochem. 2009, 44, 396-400. [CrossRef]

54. Zhou, C.; Liu, Z.; Huang, Z.L.; Dong, M.; Yu, X.L.; Ning, P. A new strategy for co-composting dairy manure with rice straw: Addition of different inocula at three stages of composting. Waste Manag. 2015, 40, 38-43. [CrossRef] [PubMed]

55. Zhao, Y.; Lu, Q.; Wei, Y.; Cui, H.; Zhang, X.; Wang, X.; Shan, S.; Wei, Z. Effect of actinobacteria agent inoculation methods on cellulose degradation during composting based on redundancy analysis. Bioresour. Technol. 2016, 219, 196-203. [CrossRef]

56. Zainudin, M.H.M.; Hassan, M.A.; Tokura, M.; Shirai, Y. Indigenous cellulolytic and hemicellulolytic bacteria enhanced rapid co-composting of lignocellulose oil palm empty fruit bunch with palm oil mill effluent anaerobic sludge. Bioresour. Technol. 2013, 147, 632-635. [CrossRef]

57. Rastogi, M.; Nandal, M.; Khosla, B. Microbes as vital additives for solid waste composting. Heliyon 2020, 6, e03343. [CrossRef] [PubMed]

58. Formowitz, B.; Elango, F.; Okumoto, S.; Müller, T.; Buerkert, A. The role of "effective microorganisms" in the composting of banana (Musa ssp.) residues. J. Plant Nutr. Soil Sci. 2007, 170, 649-656. [CrossRef]

59. Cóndor-Golec, A.F.; Pérez, P.G.; Lokare, C. Effective Microorganisms: Myth or reality? Rev. Peru. Biol. 2007, 14, 315-319. [CrossRef]

60. Mayer, J.; Scheid, S.; Widmer, F.; Fließbach, A.; Oberholzer, H.R. How effective are “Effective microorganisms ${ }^{\circledR}($ EM)”? Results from a field study in temperate climate. Appl. Soil Ecol. 2010, 46, 230-239. [CrossRef]

61. van Vliet, P.C.J.; Bloem, J.; de Goede, R.G.M. Microbial diversity, nitrogen loss and grass production after addition of Effective Micro-organisms (EM) to slurry manure. Appl. Soil Ecol. 2006, 32, 188-198. [CrossRef]

62. Che Jusoh, M.L.; Abd Manaf, L.; Abdul Latiff, P. Composting of rice straw with effective microorganisms (EM) and its influence on compost quality. Iran. J. Environ. Health Sci. Eng. 2013, 10, 17. [CrossRef] [PubMed]

63. Lim, L.Y.; Chua, L.S.; Lee, C.T. Effects of microbial additive on the physiochemical and biological properties of oil palm empty fruit bunches compost. J. Eng. Sci. Technol. 2015, 10, 10-18. 
64. Wu, D.; Wei, Z.; Qu, F.; Ahmed, T.; Zhu, L.; Zhao, Y.; Jia, L. Effect of Fenton pretreatment combined with bacteria inoculation on humic substances formation during lignocellulosic biomass composting derived from rice straw. Bioresour. Technol. 2020, 303, 122849. [CrossRef]

65. Yang, L.; Jie, G.; She-Qi, Z.; Long-Xiang, S.; Wei, S.; Xun, Q.; Man-li, D. Effects of adding compound microbial inoculum on microbial community diversity and enzymatic activity during co-composting. Environ. Eng. Sci. 2018, 35, 270-278. [CrossRef]

66. Henry, A.B.; Chaw, E.M.H.; Kim, K.Y. Metagenomic analysis reveals enhanced biodiversity and composting efficiency of lignocellulosic waste by thermoacidophilic effective microorganism (tEM). J. Environ. Manag. 2020, 276, 111252. [CrossRef]

67. Liu, H.; Huang, Y.; Duan, W.; Qiao, C.; Shen, Q.; Li, R. Microbial community composition turnover and function in the mesophilic phase predetermine chicken manure composting efficiency. Bioresour. Technol. 2020, 313, 123658. [CrossRef]

68. Cao, R.; Ben, W.; Qiang, Z.; Zhang, J. Removal of antibiotic resistance genes in pig manure composting influenced by inoculation of compound microbial agents. Bioresour. Technol. 2020, 317, 123966. [CrossRef] [PubMed]

69. Du, X.; Li, B.; Chen, K.; Zhao, C.; Xu, L.; Yang, Z.; Sun, Q.; Chandio, F.A.; Wu, G. Rice straw addition and biological inoculation promote the maturation of aerobic compost of rice straw biogas residue. Biomass Convers. Biorefineries 2020, 34, 607-622. [CrossRef]

70. Hu, T.; Wang, X.; Zhen, L.; Gu, J.; Zhang, K.; Wang, Q.; Ma, J.; Peng, H. Effects of inoculation with lignocellulose-degrading microorganisms on antibiotic resistance genes and the bacterial community during co-composting of swine manure with spent mushroom substrate. Environ. Pollut. 2019, 252, 110-118. [CrossRef]

71. Chen, Y.; Chen, Y.; Li, Y.; Wu, Y.; Zeng, Z.; Xu, R.; Wang, S.; Li, H.; Zhang, J. Changes of heavy metal fractions during cocomposting of agricultural waste and river sediment with inoculation of Phanerochaete chrysosporium. J. Hazard. Mater. 2019, 378, 120757. [CrossRef] [PubMed]

72. Xu, J.; Jiang, Z.; Li, M.; Li, Q. A compost-derived thermophilic microbial consortium enhances the humification process and alters the microbial diversity during composting. J. Environ. Manag. 2019, 243, 240-249. [CrossRef]

73. Li, C.; Li, H.; Yao, T.; Su, M.; Ran, F.; Han, B.; Li, J. Microbial inoculation influences bacterial community succession and physicochemical characteristics during pig manure composting with corn straw. Bioresour. Technol. 2019, 289, 121653. [CrossRef]

74. Duan, M.; Zhang, Y.; Zhou, B.; Wang, Q.; Gu, J.; Liu, G.; Qin, Z.; Li, Z. Changes in antibiotic resistance genes and mobile genetic elements during cattle manure composting after inoculation with Bacillus subtilis. Bioresour. Technol. 2019, 292, 122011. [CrossRef] [PubMed]

75. Wei, Y.; Wu, D.; Wei, D.; Zhao, Y.; Wu, J.; Xie, X.; Zhang, R.; Wei, Z. Improved lignocellulose-degrading performance during straw composting from diverse sources with actinomycetes inoculation by regulating the key enzyme activities. Bioresour. Technol. 2019, 271, 66-74. [CrossRef]

76. Zhao, Y.; Zhao, Y.; Zhang, Z.; Wei, Y.; Wang, H.; Lu, Q.; Li, Y.; Wei, Z. Effect of thermo-tolerant actinomycetes inoculation on cellulose degradation and the formation of humic substances during composting. Waste Manag. 2017, 68, 64-73. [CrossRef]

77. Xie, X.; Zhao, Y.; Sun, Q.; Wang, X.; Cui, H.; Zhang, X.; Li, Y.; Wei, Z. A novel method for contributing to composting start-up at low temperature by inoculating cold-adapted microbial consortium. Bioresour. Technol. 2017, 238, 39-47. [CrossRef] [PubMed]

78. Gou, C.; Wang, Y.; Zhang, X.; Lou, Y.; Gao, Y. Inoculation with a psychrotrophic-thermophilic complex microbial agent accelerates onset and promotes maturity of dairy manure-rice straw composting under cold climate conditions. Bioresour. Technol. 2017, 243, 339-346. [CrossRef]

79. Huang, C.; Zeng, G.; Huang, D.; Lai, C.; Xu, P.; Zhang, C.; Cheng, M.; Wan, J.; Hu, L.; Zhang, Y. Effect of Phanerochaete chrysosporium inoculation on bacterial community and metal stabilization in lead-contaminated agricultural waste composting. Bioresour. Technol. 2017, 243, 294-303. [CrossRef]

80. Zhang, Y.; Zhao, Y.; Chen, Y.; Lu, Q.; Li, M.; Wang, X.; Wei, Y.; Xie, X.; Wei, Z. A regulating method for reducing nitrogen loss based on enriched ammonia-oxidizing bacteria during composting. Bioresour. Technol. 2016, 221, 276-283. [CrossRef]

81. Varma, V.S.; Ramu, K.; Kalamdhad, A.S. Carbon decomposition by inoculating Phanerochaete chrysosporium during drum composting of agricultural waste. Environ. Sci. Pollut. Res. 2015, 22, 7851-7858. [CrossRef]

82. Xu, Z.; Li, R.; Wu, S.; He, Q.; Ling, Z.; Liu, T.; Wang, Q.; Zhang, Z.; Quan, F. Cattle manure compost humification process by inoculation ammonia-oxidizing bacteria. Bioresour. Technol. 2022, 344, 126314. [CrossRef] [PubMed]

83. Xu, Z.; Zhang, F.B.; Zhang, L.L.; Li, J. Effects of indigenous and exogenous microbial inocula on dynamic changes of enzyme activities during composting in a bioreactor. Adv. Mater. Res. 2012, 383-390, 4017-4023. [CrossRef]

84. Xu, P.; Li, J. Effects of Microbial Inoculant on Physical and Chemical Properties in Pig Manure Composting. Compost Sci. Util. 2017, 25, S37-S42. [CrossRef]

85. Wang, B.; Wang, Y.; Wei, Y.; Chen, W.; Ding, G.; Zhan, Y.; Liu, Y.; Xu, T.; Xiao, J.; Li, J. Impact of inoculation and turning for full-scale composting on core bacterial community and their co-occurrence compared by network analysis. Bioresour. Technol. 2022, 345, 126417. [CrossRef]

86. Zhu, N.; Zhu, Y.; Kan, Z.; Li, B.; Cao, Y.; Jin, H. Effects of two-stage microbial inoculation on organic carbon turnover and fungal community succession during co-composting of cattle manure and rice straw. Bioresour. Technol. 2021, 341, 125842. [CrossRef]

87. Wang, W.K.; Liang, C.M. Enhancing the compost maturation of swine manure and rice straw by applying bioaugmentation. Sci. Rep. 2021, 11, 6103. [CrossRef]

88. Zhu, N.; Zhu, Y.; Li, B.; Jin, H.; Dong, Y. Increased enzyme activities and fungal degraders by Gloeophyllum trabeum inoculation improve lignocellulose degradation efficiency during manure-straw composting. Bioresour. Technol. 2021, 337, 125427. [CrossRef] 
89. Kianirad, M.; Muazardalan, M.; Savaghebi, G.; Farahbakhsh, M.; Mirdamadi, S. Effects of temperature treatment on corn cob composting and reducing of composting time: A comparative study. Waste Manag. Res. 2010, 28, 882-887. [CrossRef] [PubMed]

90. Zhang, L.; Zhang, J.; Zeng, G.; Dong, H.; Chen, Y.; Huang, C.; Zhu, Y.; Xu, R.; Cheng, Y.; Hou, K.; et al. Multivariate relationships between microbial communities and environmental variables during co-composting of sewage sludge and agricultural waste in the presence of PVP-AgNPs. Bioresour. Technol. 2018, 261, 10-18. [CrossRef] [PubMed]

91. Dhyani, V.; Kumar Awasthi, M.; Wang, Q.; Kumar, J.; Ren, X.; Zhao, J.; Chen, H.; Wang, M.; Bhaskar, T.; Zhang, Z. Effect of composting on the thermal decomposition behavior and kinetic parameters of pig manure-derived solid waste. Bioresour. Technol. 2018, 252, 59-65. [CrossRef] [PubMed]

92. Xu, Z.; Li, G.; Huda, N.; Zhang, B.; Wang, M.; Luo, W. Effects of moisture and carbon/nitrogen ratio on gaseous emissions and maturity during direct composting of cornstalks used for filtration of anaerobically digested manure centrate. Bioresour. Technol. 2020, 298, 122503. [CrossRef]

93. Zeng, G.; Yu, M.; Chen, Y.; Huang, D.; Zhang, J.; Huang, H.; Jiang, R.; Yu, Z. Effects of inoculation with Phanerochaete chrysosporium at various time points on enzyme activities during agricultural waste composting. Bioresour. Technol. 2010, 101, $222-227$. [CrossRef]

94. Stefanakis, A.I.; Akratos, C.S.; Tsihrintzis, V.A. Effect of wastewater step-feeding on removal efficiency of pilot-scale horizontal subsurface flow constructed wetlands. Ecol. Eng. 2011, 37, 431-443. [CrossRef]

95. Chen, Q.L.; An, X.L.; Li, H.; Zhu, Y.G.; Su, J.Q.; Cui, L. Do manure-borne or indigenous soil microorganisms influence the spread of antibiotic resistance genes in manured soil? Soil Biol. Biochem. 2017, 114, 229-237. [CrossRef]

96. Yoshizaki, T.; Shirai, Y.; Hassan, M.A.; Baharuddin, A.S.; Raja Abdullah, N.M.; Sulaiman, A.; Busu, Z. Improved economic viability of integrated biogas energy and compost production for sustainable palm oil mill management. J. Clean. Prod. 2013, 44, 1-7. [CrossRef]

97. Chin, C.F.S.; Furuya, Y.; Zainudin, M.H.M.; Ramli, N.; Hassan, M.A.; Tashiro, Y.; Sakai, K. Novel multifunctional plant growthpromoting bacteria in co-compost of palm oil industry waste. J. Biosci. Bioeng. 2017, 124, 506-513. [CrossRef] [PubMed] 